\title{
Premiums and Stock Price Responses in Equity-Stake Purchase Deals in Korea's Stock Market
}

\author{
Jin Park, Research Professor, Korea University of Technology \& Education \\ Jungwon Suh ${ }^{* *}$, Professor, Sungkyunkwan University
}

\begin{abstract}
$\langle$ Abstract $\rangle$
In this study, we examine a sample of 160 equity-stake purchase deals between companies listed on Korea's stock market during 2009 2017. The sample comprises deals in which acquiring firms buy at least $5 \%$ of the target's common stock but excludes mergers or acquisitions of the target's entire equity. The deal premium is measured by the difference between the deal price and the target's share price a day or a week before the deal's announcement. We find that although the deal premium tends to increase with the size of the equity stake in the target, it is negative in about half of the sample and its median value is close to zero. Moreover, the deal premium is positively associated with the won value of the deal size relative to acquiring firms' assets but negatively associated with their quality (measured by operating profitability) and size of insider ownership. We also analyze stock price responses to deal announcements. For acquiring firms, the mean cumulative abnormal return over $(-2,2)$ (i.e., CAR $(-2,2))$ is not statistically significant but CAR $(-2,2)$ increases with deal premium and the target's operating performance. For target firms, the mean CAR $(-2,2)$ is significantly positive (approximately $1.6 \%$ ) but we cannot identify factors that are systematically associated with their CAR $(-2,2)$.
\end{abstract}

Keywords: Acquisition; Equity-Stake Purchase; Deal Premium; Event Study; Stock Price Response

JEL Classification: G14, G34

* This work was supported by the Ministry of Education of the Republic of Korea and the National Research Foundation of Korea (NRF-2017S1A5A2A03067521).

** Corresponding Author. Address: Business School, Sungkyunkwan University, 25-2 Sungkyunkwan-ro, Jongno-gu, Seoul, Korea 03063; E-mail: jungwonsuh@skku.edu; Tel:+82-2-760-0482; Fax:+82-2-760-0440.

Received: March 19, 2020; Revised: June 19, 2020; Accepted: July 14, 2020 


\title{
지분매입 거래의 프리미엄과 주가반응*
}

\author{
박 진 (한국기술교육대학교 연구교수) \\ 서 정 원 (성균관대학교 교수)**
}

\begin{abstract}
본 논문은 2009 2017년 기간 발생한 160건의 상장회사 간 지분매입 인수거래를 대상으로 거래 프리미엄과 공시 주가반응을 분석하였다. 분석 표본에는 인수기업이 피인수기업의 지분을 $5 \%$ 이상 취득하는 경우를 포함하였으며, 거래 프리미엄은 1 주당 거래가격과 피인수기업의 공시 직전일 (또는 1 주일 전) 종가 간의 차이로 정의하였다. 취득지분 크기와 거래 프리미엄 간에는 유의한 양(+)의 선형관계가 존재하였으나, 거래 프리미엄의 중간값은 0 에 가깝고 음 $(-)$ 의 값을 가지는 건수가 절반에 달해 양 $(+)$ 의 거래 프리미엄 지급은 일반적이지 않았다. 또한 영업성과가 좋거나 대주주 지분율이 높은 인수기업일수록 거래 프리미엄을 덜 지급하는 것으로 나타났다. 거래공시에 대한 인수기업의 평균 $\mathrm{CAR}(-2,2)$ 은 유의성이 없었으나 피인수기업의 평균 $\mathrm{CAR}(-2,2)$ 은 $1.6 \%$ 로 유의적이었다. 따라서 지분매입 거래는 인수기업보다는 피인수기업에 긍정적인 주가반응을 초래하는 것으로 보인다. 거래 프리미엄이 음(-)인 경우가 절반 정도나 되며 피인수기업의 평균 공시 주가반응이 양 $(+)$ 이라는 관측은 "강제 공개매수제도를 택하지 않는 현 법제도 하에서 지분매입 거래의 프리미엄 혜택은 피인수기업 대주주만이 누린다”는 의견을 지지하지 않는다.
\end{abstract}

핵심 단어 : 지분매입, 거래 프리미엄, 인수합병, 주가반응, 공시효과

JEL 분류기호: G14, G34

* 이 논문은 2017년 대한민국 교육부와 한국연구재단의 지원을 받아 수행된 연구임 (NRF-2017S1A5A2A03067521).

** 연락담당 저자. 주소: 서울특별시 종로구 성균관로 25-2 성균관대학교 경영대학, 03063; E-mail: jungwonsuh@skku.edu; Tel: 02-760-0482; Fax: 02-760-0440. 


\section{1. 서론}

경영권 인수(takeover) 방식에는 합병, 영업양수도 외에도 지분매입 방식이 있다. 그런데 국내 주요 저널에 실린 선행연구들은 대부분 합병에 대한 공시효과를 대상으로 하였으며(Cho and Jun, 2004; Byun and Ahn, 2007; Kang and Kim, 2009 등) 지분매입 방식의 거래에 대한 연구는 저조한 실정이다.

국내 상장사 간 합병의 경우 자본시장법의 규정에 따라 인수기업(acquirer)과 피인수기업 (target)의 최근 주가에 기초해 주식교환 비율이 결정되기 때문에 사실상 거래 프리미엄의 지불 없이 거래가 일어난다. 하지만 지분매입 거래의 경우는 인수기업과 매도자(법인 또는 개인) 간에 합의에 따라 가격이 결정되기 때문에 피인수기업의 시장가격과 거래가격 간에는 괴리(즉, 거래 프리미엄(또는 디스카운트))가 있을 수 있다.1) 본 연구의 첫 번째 주요 과제는 거래 프리미엄의 규모와 분포를 분석하고 결정요인을 탐구하는 것이다. 그리고 본 연구의 두 번째 주요 과제는 지분매입 거래의 공시가 인수기업과 피인수기업의 주가에 긍정 또는 부정적 효과를 나타내는가와 이 공시효과에 영향을 미치는 요인을 탐구하는 것이다.

표본 구축을 위해 2009 2017년 기간 동안 국내 상장사 간 이루어진 지분매입 거래를 SDC 데이터베이스로부터 추출하였으며 따라서 합병, 자산양수도, 역인수 거래는 표본에서 제외되었다. 취득지분 크기가 $5 \%$ 미만인 거래와 인수기업 또는 피인수기업이 금융회사인 거래는 제외하는 등의 조건을 부여한 결과 최종 160 건의 거래가 표본에 포함되었다. 거래 프리미엄을 측정하기 위해 각 인수거래의 주당 거래가격과 최근 주가(피인수기업)의 차이를 나타내는 두 변수를 생성하였다. 구체적으로 프리미엄(1 Day)과 프리미엄(1 Week)은 각각 “(주당 거래가격-공시 직전일 종가)/공시 직전일 종가”와 “(주당 거래가격-공시 1 주일 전 종가)/공시 1 주일 전 종가”로 정의되었다.

연구표본을 취득지분 크기로 구분할 경우 $5 \%$ 10\%의 지분 취득이 55 건, $10 \sim 20 \%$ 의 지분 취득은 48 건, $20 \sim 30 \%$ 의 지분 취득은 27 건, $30 \sim 40 \%$ 의 지분 취득은 15 건 등을 나타냈으며 $50 \%$ 이상의 취득지분 건수는 모두 7건에 불과해 피인수기업의 지분 절반 이상을 취득하는 거래는 드물었다. 거래 프리미엄을 분석한 결과 연구표본의 프리미엄(1 Day)의 평균은 $8.4 \%$, 중간값은 $-0.2 \%$ 이며 프리미엄(1 Week)의 평균은 $10.7 \%$, 중간값은 $0.5 \%$ 여서 평균은 높은 편이나 중간값은 0 에 가까웠다. 특히 음(-)의 프리미엄을 가지는 거래의 비중이 프리미엄(1 Day) 기준으로는 $50.6 \%$, 프리미엄(1 Week) 기준으로는 $45.6 \%$ 에 달해, 국내 상장기업 간 지분 거래시 양 $(+)$ 의 거래 프리미엄을 지급하는 거래의 비중이 절반이 안 되거나 겨우 절반을 넘는 것으로 나타났다. 취득지분이 높은 거래에서도 프리미엄이 음(-)의 값을 가지는 비중이 상당히 높았다. 한편 프리미엄을 종속변수, 취득지분을 설명변수로 설정한 단순 OLS 회귀식을 추정한 결과, 취득지분이 높을수록 거래 프리미엄이 높아지는 선형관계가 통계적으로는 유의함을 확인할 수 있었다.

1) 본 연구에서는 이 괴리를 거래 프리미엄이라 부르기로 한다. 가격 프리미엄 또는 경영권 프리미엄이라고 부를 수도 있다. 
Premiums and Stock Price Responses in Equity-Stake Purchase Deals in Korea's Stock Market

거래 프리미엄에 영향을 미치는 요인을 식별하기 위해 거래 프리미엄을 종속변수로 설정한 횡단면 회귀분석을 실시한 결과 거래대금-인수기업 총자산 비율이 유의한 양 $(+)$ 의 계수값을 나타내어 거래대금이 큰 거래일수록 프리미엄이 높았다. 인수기업의 ROA는 유의한 음(-)의 계수값을 나타내어 영업성과가 좋은(나쁜) 인수기업일수록 낮은(높은) 프리미엄을 지불하는 경향이 발견되었다. 또한 인수기업의 대주주 지분율은 유의한 음(-)의 계수값을 나타내어 대주주의 지배력이 높을수록 프리미엄을 덜 지급하는 것으로 보인다. 한편 피인수기업의 ROA는 계수값의 유의성이 없었다.

지분매입 거래 공시에 대한 인수기업과 피인수기업의 주가반응을 분석한 결과 인수기업의 누적초과수익률 $(\mathrm{CAR})$ 은 분석대상의 모든 윈도우에서 평균과 중간값이 0 에 가까운 수치를 나타내며 통계적 유의성이 없었다. 피인수기업의 경우 1.6\% 3.5\% 수준의 양 $(+)$ 의 값을 나타내며 통계적으로 유의하였다. 하지만 CAR의 중간값은 통계적 유의성이 없었다. 결론적으로 평균 기준으로는 지분매입 거래에 따른 공시 주가효과는 인수기업 주주들은 누리지 못하는 반면 피인수기업의 주주들은 누리는 것으로 해석된다.

또한 인수기업과 피인수기업의 공시 주가반응에 영향을 미치는 요인을 찾기 위해 주가반응 $(\mathrm{CAR}(-2,2))$ 을 종속변수로 설정한 횡단면 회귀분석을 실시하였다. 인수기업의 경우 거래 프리미엄이 높은 거래일수록 그리고 피인수기업의 영업수익성이 높을수록 긍정적인 공시 주가반응이 나타났다. 한편 다른 설명변수들은 유의한 계수값을 나타내지 않았는데 특히 거래규모가 크거나 취득지분이 크거나 인수기업의 영업성과가 높다고 해서 공시 주가반응이 달라지지는 않는 것으로 보인다. 그리고 피인수기업의 경우 주가반응에 뚜렷이 영향을 미치는 요인이 발견되지 않았다. 특히 거래 프리미엄이 높거나, 취득지분이 크거나, 인수·피인수기업의 영업성과의 높고 낮음에 따라 피인수기업의 주가반응이 달라지지는 않는 것으로 보인다.

추가 분석에서는 인수기업과 피인수기업이 대규모 기업집단 소속인가 동일 기업집단 소속 인가에 따라 거래 프리미엄의 크기와 공시 주가효과가 다르게 나타나는가를 분석하였으나 유의적인 결과를 얻을 수 없었다.

본 연구의 가장 큰 의의는 국내 인수합병거래에서 높은 비중을 차지하는 지분매입 방식의 거래를 대상으로 거래 프리미엄과 주가효과에 대해 자세한 실증분석 결과를 보고한다는 데 있다. 선행연구 중에는 $\operatorname{Kim}(2015)$ 이 국내 지분매입 거래의 프리미엄 평균값 등의 요약통계량을 보고하였으나 거래 프리미엄의 결정요인에 대해 실증분석이 이루어진 것은 본 연구가 최초이다. 또한 $\operatorname{Kim}(2015)$ 은 음(-)의 프리미엄을 나타내는 거래들을 모두 제외한 후 표본을 구축한 데 반해 본 연구는 그러한 제거 없이 프리미엄의 크기와 분포를 분석했다는 차이가 있다.

주요 분석 결과와 시사점을 정리하면 다음과 같다.

(1) 거래 프리미엄의 중간값은 0에 가깝고 음(-)의 값을 가지는 건수가 절반에 달하였기 때문에 상장회사 간 지분매입 거래시 양(+)의 프리미엄이 지불되는 것은 일반적이라고 보기 힘들다. Dyck and Zingales(2004)의 국제연구에서도 일본의 경우 지분거래의 프리미엄 평균이 음 $(-)$ 의 값 $(-4 \%)$ 을 나타내고 있어 이 결과가 예외적인 것이라고는 볼 수 없다. 
(2) 인수기업의 영업성과(ROA)가 좋을수록 그리고 대주주 지분율이 높을수록 거래 프리미엄을 덜 지급하는 것으로 나타났다. 만약 $\mathrm{ROA}$ 를 여유현금흐름의 대용치로 간주한다면 이 결과는 여유현금흐름이 큰 기업일수록 인수대금을 과잉지불한다는 가설을 지지하지 않는다. 또한 대주주 지배력이 높은 기업일수록 경영자에 대한 감시를 통해 인수대금 과잉지불이 발생하지 않는다는 해석도 가능하다.

(3) 평균적으로 지분매입 거래의 공시는 인수기업의 주가에 영향을 미치지 못하는 반면 피인수기업의 주가에는 긍정적인 주가반응을 초래한다. Byun and Ahn(2007) 등의 국내 합병 연구가 인수기업(즉, 합병기업)에 평균적으로 양 $(+)$ 의 공시효과가 나타난다고 보고하는데 비해 본 연구가 분석한 지분거래에서는 인수기업의 주가반응은 유의하지 않았다. 이는 일반적인 합병거래와 비교할 때 지분거래는 그 상대적 규모(즉, 인수기업의 기업규모에 대비한)와 중요성이 작기 때문으로 짐작된다.

(4) 인수기업의 공시 주가반응은 거래 프리미엄이 높은 거래일수록 긍정적인 것으로 나타났는데, 이는 거래 프리미엄이 높을 경우 과잉지불에 대한 우려에 의해 주가반응이 부정적일 것이라는 예측은 지지되지 않는 결과이다. 또한 영업성과가 좋은 피인수기업의 지분을 취득하는 경우 주가반응이 좋은 것으로 나타났다. 피인수기업의 경우 뚜렷이 주가반응에 유의적인 영향을 미치는 요인을 발견할 수 없었다.

(5) 위 (1)과 (3)에 서술된 결과는 "강제 공개매수제도를 택하지 않는 현 법제도 하에서 지분매입 거래의 프리미엄 혜택은 피인수기업 대주주만이 누린다"로 요약할 수 있는 Kim(2012a), Suh(2016), Park et al.(2017) 등의 비판적 의견을 지지하지는 않는다.2) 이 의견과 일관성이 있기 위해서는 지분거래의 프리미엄이 높은 양(+)을 값을 나타내고 피인수기업의 주가반응은 유의적이지 않거나 음(-)의 값을 나타내야 할 것이다. 하지만 본 연구는 지분거래의 프리미엄이 음(-)인 경우가 많으며 피인수기업의 공시 주가반응이 평균적으로 양 $(+)$ 이라는 결과를 보고하므로, 오히려 “지분거래에 의해 피인수기업의 지배주주는 손실을 보는 경우도 있지만 소수주주는 주가상승으로 단기적으로는 이익을 향유한다"는 반대의견도 가능한 것으로 보인다.3)

본 논문의 구성은 다음과 같다. 제 2 장은 관련 선행연구와 연구질문을 서술한다. 제 3 장은 표본구축과정과 주요 변수를 설명한다. 제 4 장은 연구질문에 대한 실증분석 결과를 보고하고 해석한다. 마지막으로 제 5장은 결론과 시사점을 서술한다.

2) 예를 들어 $\operatorname{Kim}(2012 \mathrm{a})$ 은 소수주주들에게도 경영권 프리미엄에 대한 이익이 지분-비례적으로 나누어져야 한다고 주장한다. 일본의 법제도에서는 인수기업이 피인수기업의 3 분의 2 이상 지분을 매입하는 거래에 대해서 공개매수를 강제하고 있다(Yeh, 2019).

3) 위 비판적 의견에서는 법 개정을 통해 지분매수시 공개매수(tender offer)를 강제함으로써 거래 프리미엄이 소수주주에게도 분배되어야 한다고 주장하지만, 공개매수 강제시 거래코스트의 증가로 인해 전반적인 거래빈도가 떨어져 그 결과 비효율적인 기업의 경영권이 빨리 교체되지 않는 문제가 생길 수 있다. 


\section{2. 관련 선행연구와 본 연구의 연구질문}

경영권은 기업의 대표권, 이사회 구성권, 업무집행권, 처분권 등과 같이 포괄적인 의미를 담고 있다(Kim, 2012a). 지분 인수거래를 통해 경영권의 이전 또는 변화가 있을 수 있으며 이에 따라 지분 인수거래시 프리미엄이 발생할 수 있다. 해외 선행연구 중 Dyck and Zingales(2004)는 $\mathrm{SDC}$ 데이터베이스에 수집한 39 개 국가의 총 393 개의 지분매입 인수거래를 분석하였는데, 프리미엄의 평균은 약 $14 \%$ 였으며 그 중에는 일본(-4\%)처럼 평균 음(-)의 프리미엄을 나타내는 국가도 있는 반면 브라질(65\%)처럼 높은 양 $(+)$ 의 프리미엄을 보인 국가도 있었다. 이 저자들은 후진국 또는 소유집중도가 높은 경우 거래 프리미엄이 높아지는 경향이 있음을 보고한다. $\operatorname{Kim}(2012 \mathrm{~b})$ 의 국제연구 또한 SDC 데이터베이스에서 구한 인수합병거래를 분석하였는데, 미국의 경우는 전체 인수합병거래에서 합병방식의 인수거래가 압도적으로 다수(84\%)인 반면 한국의 경우는 합병방식이 차지하는 비중이 $16 \%$ 정도라고 보고한다. 또한 투자자보호정도가 낮은 국가일수록 합병방식보다는 지분매입 방식이 더 빈번하게 사용된다는 패턴을 보고한다.4)

국내 선행연구 중에는 $\operatorname{Kim}(2015)$ 이 국내시장 지분 인수거래의 프리미엄 수준을 분석한 바 있으나 프리미엄의 구체적인 분포와 결정요인을 분석한 논문은 본 연구가 최초이다. 또한 본 연구는 선행연구와는 달리 지분 인수거래의 공시 주가반응을 인수기업·피인수기업 모두에 대해 분석하였다. 한편 국내 선행연구 중에는 <부록 $1>$ 에 정리되었듯이 합병거래에 대한 공시 주가반응을 분석한 논문들이 다수 있으며 이들 대부분은 합병기업(acquirer)의 공시 주가반응에 초점을 맞추어 분석하였다. 이 논문들은 합병공시에 대한 합병기업의 주가반응이 유의한 양 $(+)$ 의 값을 나타낸다는 패턴을 보고한다(Byun and Ahn, 2007; Kang and Kim, 2009; Yun and Jung, 2009; Lim et al., 2010; Kim and Jung, 2015 등).

본 연구의 주요 연구질문은 다음과 같다.

\section{연구질문 1: 지분매입 인수거래의 거래 프리미엄의 크기와 분포는?}

공식적인 조사가 없었지만 국내 합병인수 실무업계에는 국내 인수거래의 프리미엄이 높다는 의견이 존재하는 것으로 보인다. $\operatorname{Kim}(2015)$ 은 SDC 데이터베이스에서 2005 2014년 기간 국내시장에 발생한 114 건의 지분매입 인수거래를 분석하여 거래 프리미엄의 평균(중간값)이 거래 발표 1일 전 주가 대비 39.01\%(18.95\%)로 높은 수준이라고 보고한다. 하지만 Kim(2015)은 표본구축과정에서 프리미엄이 음(-)의 값을 가지는 거래를 제거하였다.5) 본 연구는 프리미엄이

4) 이 밖에 Kang and Kim(2008), Quimet(2013), Liao(2014), Povel and Sertsios(2014)는 SDC 데이터 베이스 또는 Capital IQ 데이터베이스 등을 이용해 미국 등의 국가에서의 지분매입 거래를 분석하였으나 거래 인수지분이 $50 \%$ 이하인 경우만 한정해서 분석하였기 때문에 이러한 제한 없이 표본을 구축하여 분석한 본 연구(또한 Dyck and Zingales, 2004; Kim, 2012b)와는 차이가 있다. 그리고 이 연구들은 인수거래의 프리미엄을 분석하지 않았다.

5) $\mathrm{Kim}(2015)$ 은 프리미엄이 음(-)의 값을 가지는 건수 또는 비중을 밝히지 않았는데, "경영권 프리미엄이 부의 기호를 가지는 경우는 인수대상 기업이 실적이 좋지 않아 구조조정 중이거나, 시장에 미리 인수 소식이 알려져서 주식가격이 급등한 경우를 생각해 볼 수 있다”(pp. 215)라고 서술하였다. 
한국증권학회지 제49권 5호 (2020)

음(-)의 값을 가지는 경우를 인위적으로 제외하지 않고 프리미엄의 평균, 중간값 그리고 그 분포를 분석하고자 한다.

연구질문 2: 거래 프리미엄의 크기에 영향을 미치는 요인은?

지분거래시 취득지분의 크기는 경영권을 실질적으로 획득할 수 있는가와 관계있기 때문에 취득지분이 클수록 거래 프리미엄이 높아질 것이라 예측할 수 있다. 또한 거래 프리미엄의 크기는 인수기업과 피인수기업의 영업성과에 따라 달라질 수 있다. 그러나 인수기업의 영업성과와 거래 프리미엄의 관계가 양(+) 또는 음(-)일 지는 불확실한데, 예를 들어 영업성과가 우수한 인수기업은 적극적으로 인수에 나서지 않을 수도 있지만(이 경우 음(-)의 관계 예상), 경영자의 과신 등의 이유로 과잉지급(overpayment)을 할 가능성도 있다(이 경우 양(+)의 관계 예상). 피인수기업의 영업성과는 우수할수록 인수기업이 높은 거래 프리미엄을 지불할 것이란 예측이 가능하다. 본 연구에서는 인수기업과 피인수기업의 영업성과를 $\mathrm{ROA}$ 와 $\mathrm{M} / \mathrm{B}$ (시장-장부가치 비율)을 사용하여 측정한다. 이 밖에도 인수기업이 동종업계 기업을 인수할 때(즉, 인수기업과 피인수기업이 동일산업 소속인 경우)와 대주주 지분율로 측정한 기업지배구조가 거래 프리미엄에 영향을 미치는가를 분석하고자 한다.

연구질문 3: 지분 인수도 공시는 인수기업과 피인수기업의 양(+) 또는 음(-)의 주가효과를 나타내는가?

미국기업 간 합병거래의 공시효과 연구는 합병기업의 공시 주가반응이 유의하지 않거나 다소 음(-)이라는 결과를 보고하는데(Moeller et al., 2005; Andrade et al., 2001; Fuller et al., 2002 등), 이는 합병기업의 규모에 비해 거래의 규모가 작은 경우가 많거나 과잉투자(overinvestment) 또는 과잉지급(overpayment)에 대한 우려 등이 원인으로 해석된다. 한편 미국기업 간 합병거래의 경우 피합병기업의 주가가 거의 예외 없이 양 $(+)$ 의 공시 주가반응을 나타내는데 (Andrade et al., 2001; Yilmaz and Tanyeri, 2016), 이는 경영권 프리미엄이 피합병기업의 주주에게 지급되는 것이 일반적이기 때문이다. 미국 선행연구와는 대조적으로 국내기업 간 합병에 대한 선행연구는 합병기업이 유의한 양(+)의 주가반응을 나타낸다는 것을 보고한다(Byun and Ahn, 2007; Kang and Kim, 2009; Yun and Jung, 2009; Lim et al., 2010; Kim and Jung, 2015 등). 한편 국내 선행연구 중에는 피합병기업의 공시 주가반응을 연구한 선행연구가 없는 것으로 보인다(<부록 $1>$ 선행연구 정리 참조).6)

지분매입 거래에 대한 공시 주가효과를 보고한 국내 선행연구는-저자들이 알기에는 $-\mathrm{Na}$ and Baek(2015)이 유일한데, 이 연구는 2006 2011년 기간 상장사가 인수기업으로서 실행한 86건의 지분매입 취득거래를 분석하여 공시주가반응이 비유의함을 보고한다.7) 그런데 본

6) Kang and $\operatorname{Kim}(2009)$ 의 연구표본에는 지분인수거래(주식취득)도 포함되어 있으나 지분인수거래 주가 반응의 유의성을 별도로 보고하지는 않았으며 또한 본 연구와는 달리 피인수기업의 주가반응을 분석하지 않았다.

7) Park et al.(2018)도 합병거래의 주가실적을 분석하였으나 CAR $(-90,2)$ 등의 상대적으로 긴 윈도우를 분석하였기 때문에 표에서는 제외하였다. 
Premiums and Stock Price Responses in Equity-Stake Purchase Deals in Korea's Stock Market

연구와는 달리 피인수기업이 상장사로 한정하지는 않았으며 인수지분 크기의 영향을 분석하지는 않았다. 만약 인수기업이 과잉투자 또는 과잉지급을 한다는 우려가 있다면 인수기업의 주가반응은 부정적일 수 있을 것이나 국내 합병기업의 주가반응이 긍정적임(이유는 불확실하지만)을 비추어 볼 때 지분 인수도 거래의 경우도 인수기업의 주가반응이 긍정적일 가능성이 있다. 한편 피인수기업의 경우 미국의 합병거래와는 달리 거래 프리미엄(또는 경영권 프리미엄)이 피인수 기업의 일반 주주에게는 지불되지 않기 때문에 프리미엄 요인에 의해 피인수기업의 주가반응이 긍정적일 이유는 없을 것이다. 하지만 다른 요인들에 따라 주가반응이 긍정 또는 부정으로 나타날 수 있을 것이다.

연구질문 4: 위 공시 주가효과에 영향을 미치는 요인은 무엇인가?

인수기업과 피인수기업의 공시 주가반응은 다양한 요인에 의해 영향받을 수 있다. 인수기업의 주가반응은 거래 프리미엄이 높을 경우 과잉지급에 의한 우려 때문에 음(-)이 될 가능성이 있는 반면, 높은 프리미엄이 인수 후 기대되는 긍정적인 성과를 반영한다면 주가반응은 양(+)이 될 수 있다. 피인수기업의 주가반응의 경우 국내법의 특성상 거래 프리미엄이 일반 주주에게 지급되지 않기 때문에 프리미엄과 피인수기업의 주가 간에는 직접적인 관계는 존재하지 않는다. 하지만, 프리미엄 크기가 향후 피인수기업의 성과를 시그널한다면 긍정적으로 작용할 수도 있을 것이다.

본 연구는 인수기업과 피인수기업의 영업성과가 공시 주가반응과 관련을 가지는가도 분석한다. 미국의 선행연구 중에는 영업성과가 우수한 합병기업이 영업성과가 열등한 합병기업을 인수할 경우 합병기업의 주가반응이 긍정적이라는 연구결과가 있다(Servaes, 1991). 이 밖에도 동종산업 내 인수거래인가의 여부, 대주주 지분율로 측정한 기업지배구조의 영향도 분석하고자 한다.

\section{3. 표본 구축과 주요 측정치}

\section{1 표본 구축}

본 연구는 2009 2017년 기간 동안 국내 상장사 간 이루어진 지분매입 인수거래를 대상으로 표본을 구축하였는데 지분매입 인수거래는 SDC 데이터베이스에서 확보하였다.8) 자세한 최종표본 과정은 <부록 2>에 서술하였다.9) 먼저 1단계에서는 SDC 데이터베이스를 이용해 기간(2009.01.01 2017.12.31)과 인수기업 및 피인수기업의 국가(한국)를 한정하였으며 2단계

8) $\mathrm{SDC}$ 데이터베이스의 국내 기업의 지분거래 딜 자료는 다음 두 종류의 공시자료에 기반해 구축되고 있는 것으로 보인다: (1) 자산양수도 거래 중 주식취득 거래와 (2) 지분변동신고서.

9) $\mathrm{SDC}$ 데이터베이스로부터 2001년부터의 자료를 수집하였으나 2000년대 초·중반에는 <부록 2>의 조건(1 9)을 만족하는 거래가 거의 없어 2009년부터 표본을 구성하였다. 구체적으로 2001 2008에 대해 위 조건을 만족하는 거래는 7건 밖에 되지 않았다. 이 기간에도 많은 수의 지분매입 거래가 데이터베이스에서 존재하였으나 취득지분과 거래대금 등의 거래에 대한 구체적인 정보가 누락되어 있는 경우가 많았으며 이는 데이터베이스 구축회사 측의 backfilling 때문인 것으로 추측된다. 
한국증권학회지 제49권 5호 (2020)

에서는 합병, 자산양수도, 역인수 등을 제외하고 지분매입 거래만을 포함시켰다. 3 단계에서는 공개매입(tender offer) 방식의 거래이거나 인수기업 또는 피인수기업이 비공개회사인 거래를 제외하였으며, 4 단계에서는 인수기업 또는 피인수기업이 금융회사인 경우를 제외하였다. 5 단계 에서는 취득지분이 $5 \%$ 미만이거나 취득 후 인수회사의 지분이 $100 \%$ 가 된 거래를 제외하였다. 6 단계에서는 인수기업 또는 피인수기업이 한 해에 인수거래를 반복적으로 실시한 경우 그 해의 첫 번째 거래만을 표본에 포함하였다.10) 7 9단계에서는 취득지분, 거래대금, 프리미엄 등 주요 변수를 구할 수 없는 거래를 제외하였다. 그 결과 총 160 건의 지분 인수거래가 표본에 포함되었다.

본 연구에서는 취득지분이 최소 $5 \%$ 인 거래(즉, 인수기업이 취득하는 피인수기업의 지분이 피인수기업 전체 지분의 $5 \%$ 이상인 거래)만을 표본에 포함하였는데, 본 논문처럼 $\mathrm{SDC}$ 데이터 베이스를 사용해 지분거래를 수집한 Dyck and Zingales(2004)는 취득지분이 $10 \%$ 이상인 거래를 표본에 포함하였다. 표본 구축시 최소 취득지분을 어떻게 설정할 것인가는 자의성이 개입될 수가 있는데, 현행법상 $5 \%$ 이상의 주식을 보유한 자는 금융위원회와 한국거래소에 신고할 의무가 있다(자본시장법 147조)는 점에 비추어 5\%를 중요한 cut-off line으로 판단하였다. 물론 $5 \%$ 정도의 취득지분으로는 경영권을 획득할 수 없지만 기존 경영층의 의사결정에 영향력을 가지는 크기이며 주가를 움직일 수 있는 크기라고 볼 수 있다.11)

〈표 1〉 지분매입 인수거래의 분포

표본에 포함된 160건의 인수거래(2009 2017년 기간)에 대해 연도별 건수와 인수기업(피인수기업)의 유가증권시장·코스닥시장 소속에 따른 건수 및 대규모 기업집단 소속 여부에 따른 건수를 보고한다. 대기업 기업집단 소속 여부의 판단은 공정거래위원회 자료를 사용하였다.

\begin{tabular}{|c|c|c|c|c|c|c|c|c|c|}
\hline \multirow[b]{2}{*}{ 연도 } & \multirow[b]{2}{*}{ 건수 } & \multicolumn{2}{|c|}{ 인수기업 } & \multicolumn{2}{|c|}{ 피인수기업 } & \multicolumn{2}{|c|}{ 인수기업 } & \multicolumn{2}{|c|}{ 피인수기업 } \\
\hline & & 유가증권 & 코스닥 & 유가증권 & 코스닥 & $\begin{array}{c}\text { 대규모 } \\
\text { 기업집단 }\end{array}$ & Others & $\begin{array}{c}\text { 대규모 } \\
\text { 기업집단 }\end{array}$ & Others \\
\hline 2009 & 13 & 6 & 7 & 4 & 9 & 5 & 8 & 2 & 11 \\
\hline 2010 & 18 & 8 & 10 & 3 & 15 & 4 & 14 & 2 & 16 \\
\hline 2011 & 15 & 6 & 9 & 3 & 12 & 5 & 10 & 1 & 14 \\
\hline 2012 & 14 & 9 & 5 & 6 & 8 & 3 & 11 & 3 & 11 \\
\hline 2013 & 18 & 8 & 10 & 7 & 11 & 3 & 15 & 2 & 16 \\
\hline 2014 & 14 & 7 & 7 & 6 & 8 & 6 & 8 & 3 & 11 \\
\hline 2015 & 18 & 6 & 12 & 4 & 14 & 2 & 16 & 1 & 17 \\
\hline 2016 & 25 & 10 & 15 & 7 & 18 & 6 & 19 & 4 & 21 \\
\hline 2017 & 25 & 6 & 19 & 4 & 21 & 4 & 21 & 2 & 23 \\
\hline 합계 & 160 & 66 & 94 & 44 & 116 & 38 & 122 & 20 & 140 \\
\hline
\end{tabular}

10) 모든 filtering을 거치고 난 후 최종표본에서 제거된 6 단계의 반복거래는 총 37 건인데 이중 동일 인수기업-피인수기업 쌍(pair)에 대한 반복거래가 20건 이상을 차지하였다. 이 반복거래는 동일 회사 동일년도의 기업특성이 반복적으로 분석 결과에 영향에 미치는 것을 막기 위해 제거하였다.

11) Elliott 등의 주주행동주의 펀드(즉, 액티비스트 펀드)들은 취득지분 $5 \%$ 가 안 되는 지분매입으로도 경영과 주가에 영향을 미치곤 한다. 또한 최근 한진칼의 경영권 분쟁 사례에서 반도건설은 한진칼 보유지분율을 $6.28 \%$ 에서 $8.28 \%$ 로 늘린 후 보유목적을 단순취득에서 경영참여로 변경해 공시한 바 있다(매일경제, 2020년 2월 10일). 
Premiums and Stock Price Responses in Equity-Stake Purchase Deals in Korea's Stock Market

표본에 포함된 지분거래의 거래대금, 취득지분, 인수·피인수기업의 소속 산업 등은 $\mathrm{SDC}$ 데이터베이스에서 수집하였으며, 이외 주가수익률과 재무제표 변수 등은 에프앤가이드(FnGuide) 에서 수집하였다.12) <표 1>은 표본에 포함된 지분거래에 대해 인수기업과 피인수기업의 유가증권시장·코스닥시장 소속에 따른 연도별 분포와 대규모기업집단 소속 여부에 따른 연도별 분포를 보고한다. 피인수기업은 코스닥시장에 상장된 경우가 두 배 이상 많았으며, 대규모 기업집단에 소속된 인수기업은 160 건 중에서 38 건으로 나타났다.

\section{2 주요 측정치 정의}

본 연구의 주요 변수인 거래 프리미엄은 식 (1)과 식 (2)에 정의된 프리미엄(1 Day)과 프리미엄(1 Week)으로 측정하였는데, 구체적으로 이 변수들은 주당 거래가격이 각각 공시 하루 전 또는 1 주일 전 피인수기업의 종가보다 높은 정도를 나타낸다.

$$
\begin{aligned}
& \text { 프리미엄 }(1 \mathrm{Day})=\frac{\text { 주당거래가격 }- \text { 공시 하루 전 피인수기업의 종가 }}{\text { 공시 하루 전 피인수기업의 종가 }} \\
& \text { 프리미엄 }(1 \mathrm{Week})=\frac{\text { 주당 거래가격 }- \text { 공시 일주일 전 피인수기업의 종가 }}{\text { 공시 일주일 전 피인수기업의 종가 }}
\end{aligned}
$$

지분거래 공시가 인수기업과 피인수기업의 주가에 미치는 영향을 분석하는 사건연구를 실시 하기 위해 필요한 누적초과수익률(CAR)은 식 (3)과 식 (4)를 이용해 산출하였다. 공시일 기점으로 -240 일부터 -20 일까지의 종합주가지수 수익률을 바탕으로 알파와 베타값을 구하였으며, 기업의 일별 수익률에서 차감하여 $\mathrm{t}$ 일의 일별 초과수익률 $\left(\mathrm{AR}_{\mathrm{it}}\right)$ 을 계산한 후 여러 윈도우에 대해 누적수익률을 계산하였다.

$$
\begin{aligned}
& \mathrm{AR}_{\mathrm{it}}=\mathrm{R}_{\mathrm{it}}-\left(\alpha_{\mathrm{i}}+\beta_{\mathrm{i}} \times \mathrm{R}_{\mathrm{mt}}\right) \\
& \mathrm{CAR}_{\mathrm{i}}\left(\mathrm{t}_{1}, \mathrm{t}_{2}\right)=\sum_{t_{1}}^{t_{2}} \mathrm{AR}_{\mathrm{it}}
\end{aligned}
$$

여기서, $\mathrm{AR}_{\mathrm{it}}=$ 기업 $\mathrm{i}$ 의 $\mathrm{t}$ 일 일별 초과수익률

$\mathrm{R}_{\mathrm{it}}=$ 기업 $\mathrm{i}$ 의 $\mathrm{t}$ 일 일별 수익률

$\mathrm{R}_{\mathrm{mt}}=\mathrm{t}$ 일 일별 시장 $(\mathrm{m})$ 수익률

\section{4. 실증분석}

\section{1 주요 변수의 기술통계량}

<표 2>는 본 연구가 분석하는 주요 변수들에 대해 기술통계량을 보고한다. 패널 $\mathrm{A}$ 는 취득지분과 거래 프리미엄 등의 거래 특성변수를 보고하는데, 표본에 포함된 160 건 거래의 취득지분 평균

12) 본 연구의 저자들은 $\mathrm{SDC}$ 에서 추출한 표본의 신뢰성 확보를 위해 표본에 포함된 거래 중 20 여 개에 대해 신문 기사 등으로 인수대금과 공시일 등의 정보가 일치함을 확인하였다. 
한국증권학회지 제49권 5호 (2020)

(중간값)은 $18.9 \%(14.1 \%)$ 로 나타났다. 프리미엄(1 Day)과 프리미엄(1 Week)의 평균은 각각 0.084 와 0.107 로 양 $(+)$ 의 값을 가지지만 중간값은 각각 -0.002 와 0.005 로 영(0)에 가까워 거래 프리미엄이 음(-)인 인수거래가 상당히 많을 것임을 시사한다.

패널 $\mathrm{B}$ 는 인수기업 특성변수의 기술통계량을 보고하는데, 직전년도 총자산 대비 거래대금 비율의 평균은 0.093 이었으며 $\mathrm{ROA}$ 와 $\mathrm{M} / \mathrm{B}$ 의 평균은 각각 0.030 과 1.867 로 나타났다. 부채비율의 평균은 0.255 이었고, 최대주주 및 특수관계인의 지분을 포함한 대주주 지분율의 평균은 0.331 로 나타났다. 패널 $\mathrm{C}$ 는 피인수기업 특성변수의 기술통계량을 보고하는데, 총자산 대비 거래대금 비율의 평균은 0.201로 인수기업의 수치(0.093)보다 높게 나타났는데 이는 피인수기업이 인수 기업에 비해 일반적으로 기업규모가 작은 현상을 반영하는 것으로 보인다. 한편 피인수기업의 $\mathrm{ROA}$ 와 $\mathrm{M} / \mathrm{B}$ 의 평균은 각각 -0.017 과 2.302로 나타났다. 따라서 인수기업에 비해 피인수기업은

\section{〈표 2〉 주요 변수의 기술통계량}

표본에 포함된 160건의 인수거래(2009 2017년 기간)의 거래 특성변수(패널 A), 인수기업 특성변수(패널 $\mathrm{B}$ ), 피인수기업 특성변수(패널 C)에 대해 기술통계량을 보고한다. 각 변수의 정의는 <부록 $3>$ 에 제시되었다. 표에 포함된 모든 변수는 분포의 위아래 $1 \%$ 에서 winsorizing 하였다.

패널 $\mathrm{A}$ : 거래 특성변수

\begin{tabular}{lccrrrrrr}
\hline & 건수 & 평균 & 중간값 & 표준편차 최소값 & $\mathrm{Q} 1$ & $\mathrm{Q} 3$ & 최대값 \\
\hline 취득지분 & 160 & 0.189 & 0.141 & 0.141 & 0.050 & 0.087 & 0.254 & 0.764 \\
프리미엄(1 Day) & 160 & 0.084 & -0.002 & 0.413 & -0.348 & -0.105 & 0.065 & 2.147 \\
프리미엄(1 Week) & 160 & 0.107 & 0.005 & 0.437 & -0.348 & -0.092 & 0.111 & 2.267 \\
프리미엄금액(1 Day) & 160 & 0.007 & 0.000 & 0.046 & -0.093 & -0.004 & 0.001 & 0.205 \\
프리미엄금액(1 Week) & 160 & 0.007 & 0.000 & 0.048 & -0.105 & -0.003 & 0.003 & 0.208 \\
\hline
\end{tabular}

패널 $\mathrm{B}$ : 인수기업 특성변수

\begin{tabular}{lrrrrrrrr}
\hline & 건수 & 평균 & 중간값 표준편차 최소값 & Q1 & Q3 & 최대값 \\
\hline 거래대금/총자산 & 160 & 0.093 & 0.040 & 0.131 & 0.000 & 0.010 & 0.129 & 0.601 \\
인수기업규모 & 160 & 26.751 & 26.285 & 2.116 & 23.862 & 25.201 & 28.049 & 31.871 \\
$\mathrm{ROA}$ & 160 & 0.030 & 0.036 & 0.079 & -0.188 & 0.009 & 0.073 & 0.205 \\
$\mathrm{M} / \mathrm{B}$ & 160 & 1.867 & 1.087 & 2.821 & 0.371 & 0.822 & 1.711 & 17.520 \\
부채비율 & 160 & 0.255 & 0.251 & 0.179 & 0.000 & 0.079 & 0.399 & 0.605 \\
대주주 지분율 & 160 & 0.331 & 0.310 & 0.181 & 0.015 & 0.183 & 0.438 & 0.871 \\
\hline
\end{tabular}

패널 C: 피인수기업 특성변수

\begin{tabular}{lrrrrrrrr}
\hline & 건수 & 평균 & 중간값 & 표준편차 최소값 & $\mathrm{Q} 1$ & $\mathrm{Q} 3$ & 최대값 \\
\hline 거래대금/총자산 & 160 & 0.201 & 0.129 & 0.219 & 0.010 & 0.052 & 0.248 & 0.927 \\
피인수기업규모 & 160 & 25.451 & 25.209 & 1.243 & 23.285 & 24.597 & 26.384 & 28.890 \\
$\mathrm{ROA}$ & 160 & -0.017 & 0.007 & 0.103 & -0.283 & -0.082 & 0.057 & 0.174 \\
$\mathrm{M} / \mathrm{B}$ & 160 & 2.302 & 1.278 & 3.278 & 0.498 & 0.962 & 2.179 & 20.029 \\
부채비율 & 160 & 0.295 & 0.260 & 0.213 & 0.000 & 0.126 & 0.479 & 0.701 \\
대주주 지분율 & 160 & 0.323 & 0.301 & 0.157 & 0.015 & 0.209 & 0.434 & 0.785 \\
\hline
\end{tabular}


Premiums and Stock Price Responses in Equity-Stake Purchase Deals in Korea's Stock Market

$\mathrm{ROA}$ 로 측정한 수익성이 낮은 것으로 보인다. $\mathrm{M} / \mathrm{B}$ 의 경우는 일반적으로 규모가 작은 기업일수록 높은 경향이 있기 때문에 피인수기업의 높은 $\mathrm{M} / \mathrm{B}$ 가 긍정적인 사업전망을 나타내는가에 대해서는 판단을 유보하고자 한다.

\section{2 거래 프리미엄 분석}

\subsection{1 취득지분(\%)과 거래 프리미엄 간의 관계}

$<$ 표 3>은 연구표본을 취득지분 크기로 구분한 거래 프리미엄의 분포를 보고한다. $5 \% \sim 10 \%$ 의 지분 취득이 55 건으로 가장 많았으며, $10 \sim 20 \%$ 의 지분 취득은 48 건, $20 \sim 30 \%$ 의 지분 취득은 27 건, 30 40\%의 지분 취득은 15 건 등으로 취득지분의 크기가 커질수록 거래 건수가 낮아지는 패턴이 나타났다. 특히 $50 \%$ 이상의 취득지분 건수는 모두 7 건으로 전체 표본(160건)의 $5 \%$ 에 미치지 못해 피인수기업의 지분 절반 이상을 취득하는 거래는 드물었다.

취득지분과 거래 프리미엄 간의 관계를 살펴보자면, $5 \sim 10 \%$ 지분 취득의 거래 프리미엄은 낮은 편이여서 프리미엄(1 Day)은 평균 $0.6 \%$, 중간값 $-0.9 \%$ 이며 $10 \sim 20 \%$ 지분 취득의 경우도 평균은 $5 \%$ 로 높지만 중간값은 $-3 \%$ 로 낮은 값을 나타내었다. 두 구간 모두 프리미엄(1 Day)이 음 $(-)$ 의 값을 가지는 거래의 비중은 절반 이상이다. 이처럼 두 구간에서 프리미엄의 평균과 중간값이 낮고 프리미엄이 음(-)인 거래 비중이 높은 결과는 프리미엄(1 Week)을 분석하여도 마찬가지로 얻을 수 있다. 프리미엄이 평균과 중간값 모두 상당히 높은 수준을 나타내는 구간은 취득지분 20 30\% 구간인데, 프리미엄(1 Day)의 평균과 중간값은 각각 $19.5 \%, 4.4 \%$ 로 높았다. 하지만 이 구간에서도 음(-)의 프리미엄을 나타내는 거래의 비중이 $37 \%$ 나 달하였다.

전체 표본에 대해 분석할 경우 프리미엄( $1 \mathrm{Day})$ 의 평균은 $8.4 \%$, 중간값은 $-0.2 \%$ 이며 프리미엄(1 Week)의 평균은 $10.7 \%$, 중간값은 $0.5 \%$ 여서 평균은 높은 편이나 중간값은 0 에

\section{〈표 3〉 취득지분과 거래 프리미엄 간의 관계}

표본에 포함된 160 건의 인수거래(2009 2017년 기간)의 취득지분 크기(\%) 구간 별 거래 건수와 거래 프리미엄의 평균과 중간값을 보고한다. t-test와 Wilcoxon's z-test를 사용하여 프리미엄의 평균과 중간값이 0보다 유의하게 높은지 검증하였으며 ${ }^{* * *},{ }^{* *}$, *는 각각 $1 \%, 5 \%, 10 \%$ 수준의 유의성을 나타낸다.

\begin{tabular}{|c|c|c|c|c|c|c|c|c|c|}
\hline \multirow{2}{*}{$\begin{array}{c}\text { 취득지분 } \\
\text { 크기 }\end{array}$} & \multicolumn{3}{|c|}{ 신규매입 vs. 추가매입 건수 } & \multicolumn{3}{|c|}{ 프리미엄(1 Day) } & \multicolumn{3}{|c|}{ 프리미엄(1 Week) } \\
\hline & 총 건수 & 신규매입 & 추가매입 & 평균 & 중간값 & $\begin{array}{c}\text { 음의 값 } \\
\text { 비중 }\end{array}$ & 평균 & 중간값 & $\begin{array}{c}\text { 음의 값 } \\
\text { 비중 }\end{array}$ \\
\hline $5 \% \sim 10 \%$ & 55 & 33 & 22 & 0.006 & -0.009 & 0.545 & 0.010 & 0.004 & 0.473 \\
\hline $10 \% \sim 20 \%$ & 48 & 32 & 16 & 0.050 & -0.030 & 0.583 & 0.074 & -0.019 & 0.542 \\
\hline $20 \% \sim 30 \%$ & 27 & 18 & 9 & $0.195^{* *}$ & $0.044^{*}$ & 0.370 & $0.217^{* *}$ & $0.065^{* *}$ & 0.333 \\
\hline $30 \% \sim 40 \%$ & 15 & 8 & 7 & 0.067 & -0.038 & 0.533 & 0.122 & 0.018 & 0.467 \\
\hline $40 \% \sim 50 \%$ & 8 & 6 & 2 & 0.420 & 0.013 & 0.375 & 0.478 & 0.013 & 0.375 \\
\hline $50 \% \sim 60 \%$ & 4 & 1 & 3 & 0.220 & 0.120 & 0.250 & 0.320 & 0.230 & 0.250 \\
\hline $60 \% \sim 70 \%$ & 2 & 2 & 0 & -0.073 & -0.073 & 0.500 & -0.063 & -0.063 & 0.500 \\
\hline $70 \%$ 이상 & 1 & 1 & 0 & 0.262 & 0.262 & 0.000 & 0.268 & 0.268 & 0.000 \\
\hline 전체 표본 & 160 & 101 & 59 & $0.084^{* *}$ & -0.002 & 0.506 & $0.107^{* * *}$ & 0.005 & 0.456 \\
\hline
\end{tabular}


가까워 거래 프리미엄의 분포는 높은 우측왜도를 나타낸다. 특히 전체 표본에서 음(-)의 프리미엄을 가지는 거래의 비중이 프리미엄(1 Day) 기준으로는 $50.6 \%$, 프리미엄(1 Week) 기준으로는 $45.6 \%$ 에 달해, 국내 상장기업 간 지분 인수거래시 양 $(+)$ 의 거래 프리미엄을 지급하는 거래의 비중이 절반이 안 되거나 겨우 절반을 넘는 것으로 나타났다.

<그림 1>은 거래 프리미엄과 취득지분 간의 산포도와 OLS 회귀식을 보고한다. 산포도 역시 프리미엄이 음(-)의 값(0 이하)인 거래가 상당히 큰 비중을 차지함을 나타내며, 특히 취득지분이 높은 거래에서도 프리미엄이 음(-)의 값을 가지는 경우가 상당히 많음을 나타낸다. 이는 프리미엄

〈그림 1〉거래 프리미엄과 취득지분 간 산포도와 회귀식

표본에 포함된 160건의 인수거래(2009 2017년 기간)에 대해 거래 프리미엄과 취득지분 간의 산포도와 회귀선을 보고한다. 실선은 OLS 회귀선이며 음영구역은 confidence interval, 파선은 prediction limit을 나타낸다.

패널 A: 프리미엄(1 Day)과 취득지분(추정 회귀식의 취득지분 계수: 0.5400(t-값 = 2.36))

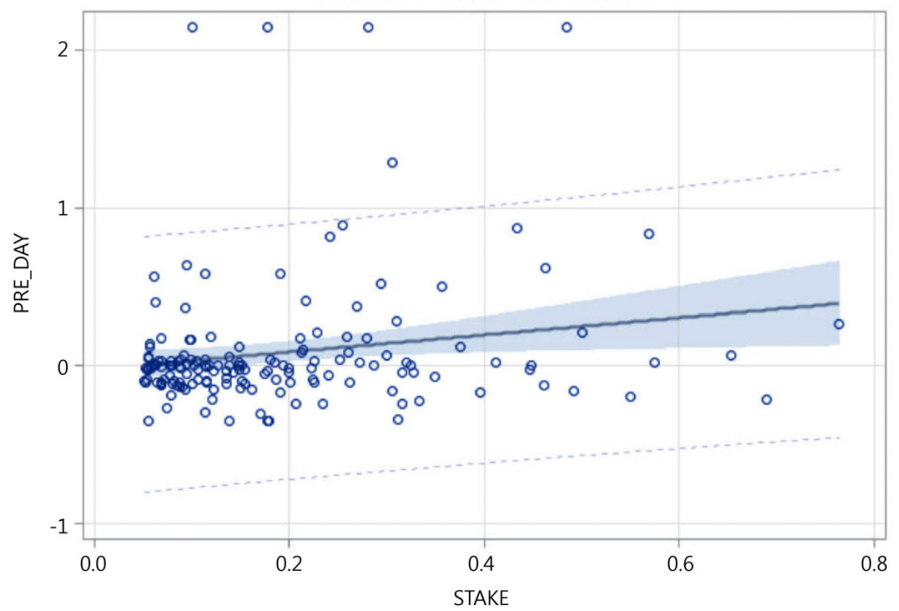

패널 B: 프리미엄(1 Week)과 취득지분(추정 회귀식의 취득지분 계수: $0.6448(\mathrm{t}-$ 값 $=2.68)$ )

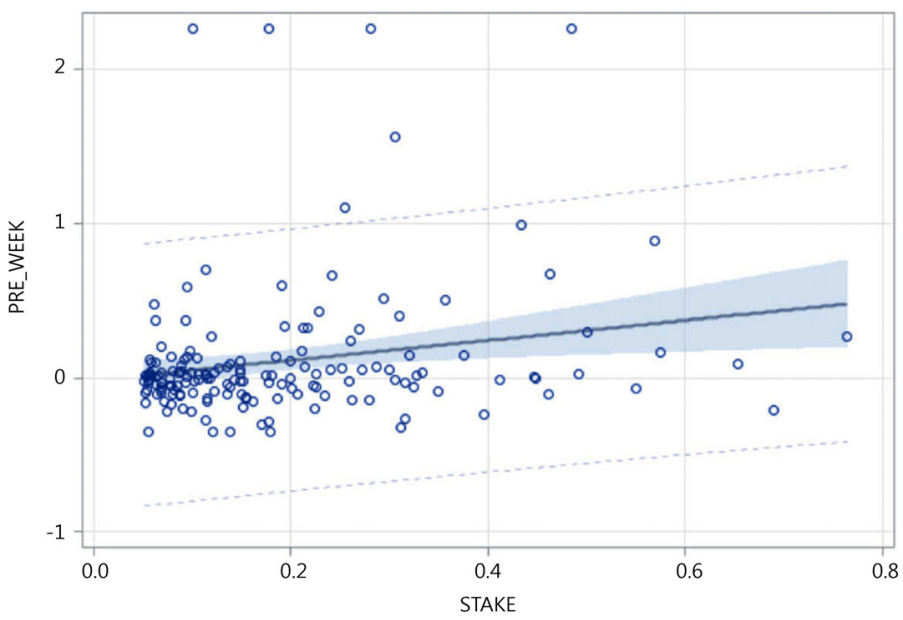


Premiums and Stock Price Responses in Equity-Stake Purchase Deals in Korea's Stock Market

(1 Day) 패널 $\mathrm{A}$ 와 프리미엄(1 Week) 패널 $\mathrm{B}$ 에서 공통적으로 얻을 수 있는 패턴이다. 한편 프리미엄을 종속변수, 취득지분을 설명변수로 하여 단순 OLS 회귀식을 추정한 결과, 프리미엄(1 Day)과 프리미엄(1 Week) 모두 취득지분의 계수값이 통계적으로 유의한 양(+)이었다. 따라서 취득지분이 높을수록 거래 프리미엄이 증가하는 선형관계가 통계적으로는 유의함을 확인할 수 있었다.

\subsection{2 거래 프리미엄에 대한 횡단면 회귀분석}

<표 4>에서는 거래 프리미엄에 영향을 미치는 요인을 식별하기 위해 거래 프리미엄을 종속변수로 설정한 횡단면 회귀분석을 실시한다. 종속변수는 프리미엄(1 Day) 패널 A와 프리미엄(1 Week) 패널 $\mathrm{B}$ 이며 회귀분석에 사용된 기업특성변수는 거래 직전년도 말 수치를 사용해 계산하였다.

패널 $\mathrm{A}$ 는 거래 프리미엄(1 Day)이 종속변수인 회귀분석 결과를 보고하는데, 거래대금/ 총자산은 사용된 모든 칼럼([1], [2], [9], [10])에서 유의한 양(+)의 계수값을 나타내고 있어 거래대금이 큰 거래일수록 프리미엄을 높게 지불하는 경향이 있음을 시사한다. 한편 취득지분의 경우 칼럼 [2], [4], [6], [8]에서 유의한 양 $(+)$ 의 값을 나타내고 있어 앞서 <그림 $1>$ 에서 보고한 취득지분과 프리미엄 간의 양(+)의 관계를 재확인해 주고 있다. 하지만 칼럼 [10]에서 여러 설명변수들을 추가해 분석하였을 때는 취득지분의 유의성은 사라졌다. 한편 인수기업과 피인수기업의 수익성 $(\mathrm{ROA})$ 을 분석한 칼럼 [3] [4]의 경우 인수기업의 ROA가 유의한 음(-)의 계수값을 나타내었으며 다른 설명변수들을 추가해 분석한 칼럼 [9] [10]에서도 유의적인 음(-)의 계수값이 유지되었다.13) 또한 영업성과를 반영한다고 가정할 수 있는 시장가치-장부가치 비율도 유사한 결과를 나타내는데, 칼럼 [5] [6]에서 $\mathrm{M} / \mathrm{B}$ (인수)(즉, 인수기업의 시장가치-장부가치 비율)의 계수값은 유의한 음(-)값을 나타내며 이는 칼럼 [9] [10]에서도 유지되었다. 이 결과는 영업성과가 좋은(나쁜) 인수기업일수록 낮은(높은) 프리미엄을 지불하는 경향이 있음을 시사한다.

한편 동종업계 더미는 칼럼 [7]에서는 계수값의 유의성이 없으나 칼럼 [8] 등에서 계수값의 유의성이 나타나는데, 이는 회귀식에 추가된 다른 변수들이 동종업계 더미에 영향을 미치면서 나타난 가성적(spurious)인 결과로 판단된다. 따라서 동종업계 거래일 경우 프리미엄을 더 지급한다는 가설이 충분히 지지된다고는 판단할 수 없다. 또한 대주주 지분율도 설명변수로 포함된 대부분의 회귀식에서 계수값의 유의성이 없었다.

패널 $\mathrm{B}$ 는 프리미엄(1 Week)을 종속변수로 한 추정 결과인데, 대체적으로 패널 $\mathrm{A}$ 와 질적으로 동일한 결과를 보고한다. 거래대금/총자산은 사용된 모든 칼럼에서 유의한 양(+)의 계수값이 관찰되었으며 거래규모가 큰 거래일수록 프리미엄을 높게 지급하는 것으로 보인다. 인수기업의 $\mathrm{ROA}$ (즉, $\mathrm{ROA}$ (인수)) 또한 사용된 모든 칼럼에서 음(-)의 계수값을 나타내어 영업성과가 좋은(나쁜) 인수기업일수록 낮은(높은) 프리미엄을 지불하는 경향이 재확인되었다. 하지만 $\mathrm{M} / \mathrm{B}$ (인수)의 경우는-패널 $\mathrm{A}$ 에서와는 달리—칼럼 [5] [6]에서 유의성이 사라졌다.

13) 표에 보고되지는 않았으나 $\mathrm{ROA}$ (=영업이익/총자산) 대신에 순이익마진(=당기순이익/매출액)이나 $\mathrm{ROE}$ (=당기순이익/자본총계)를 설명변수로 사용하였을 경우에도 질적으로 동일한 회귀계수값을 얻을 수 있었다. 


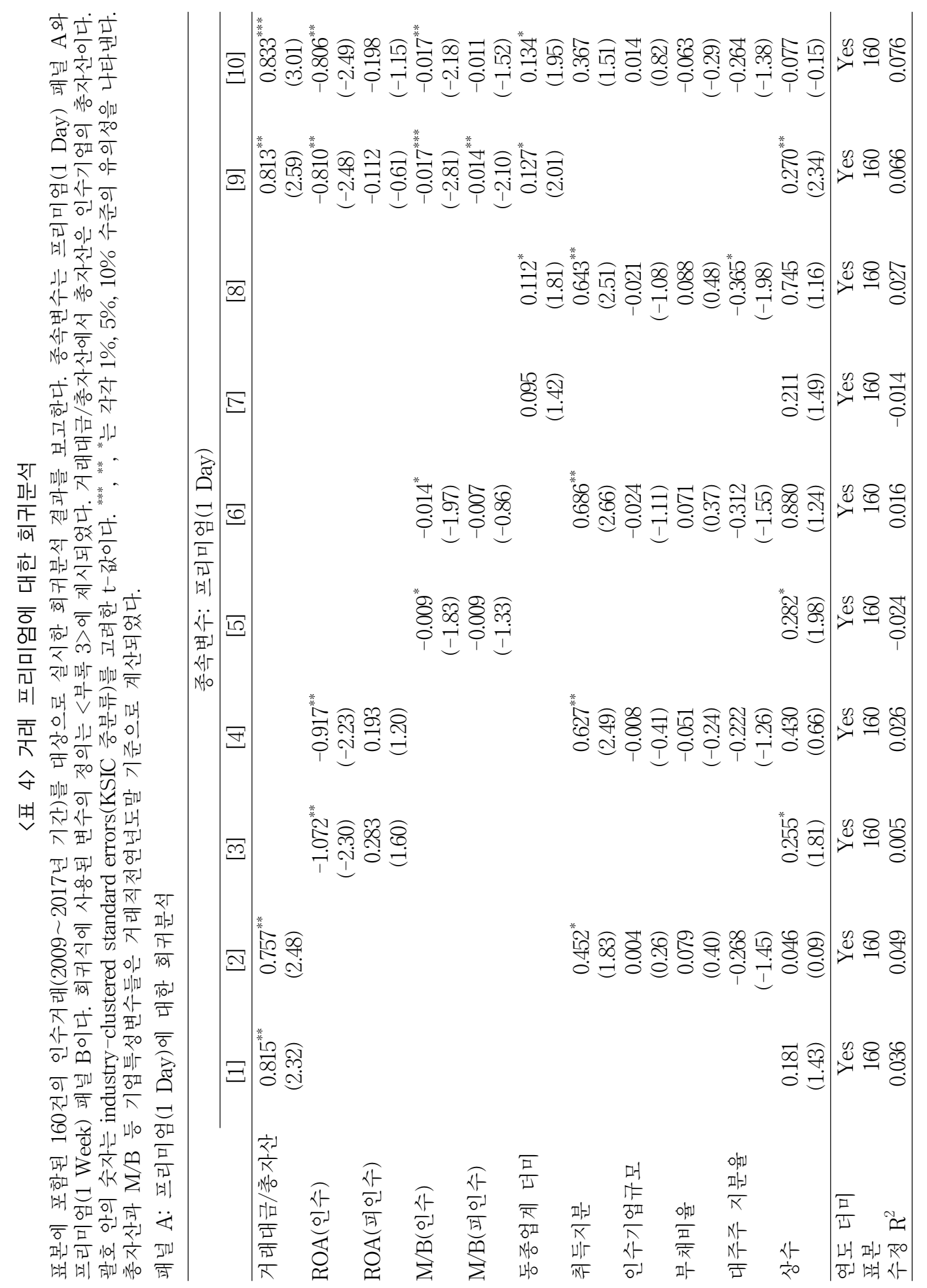




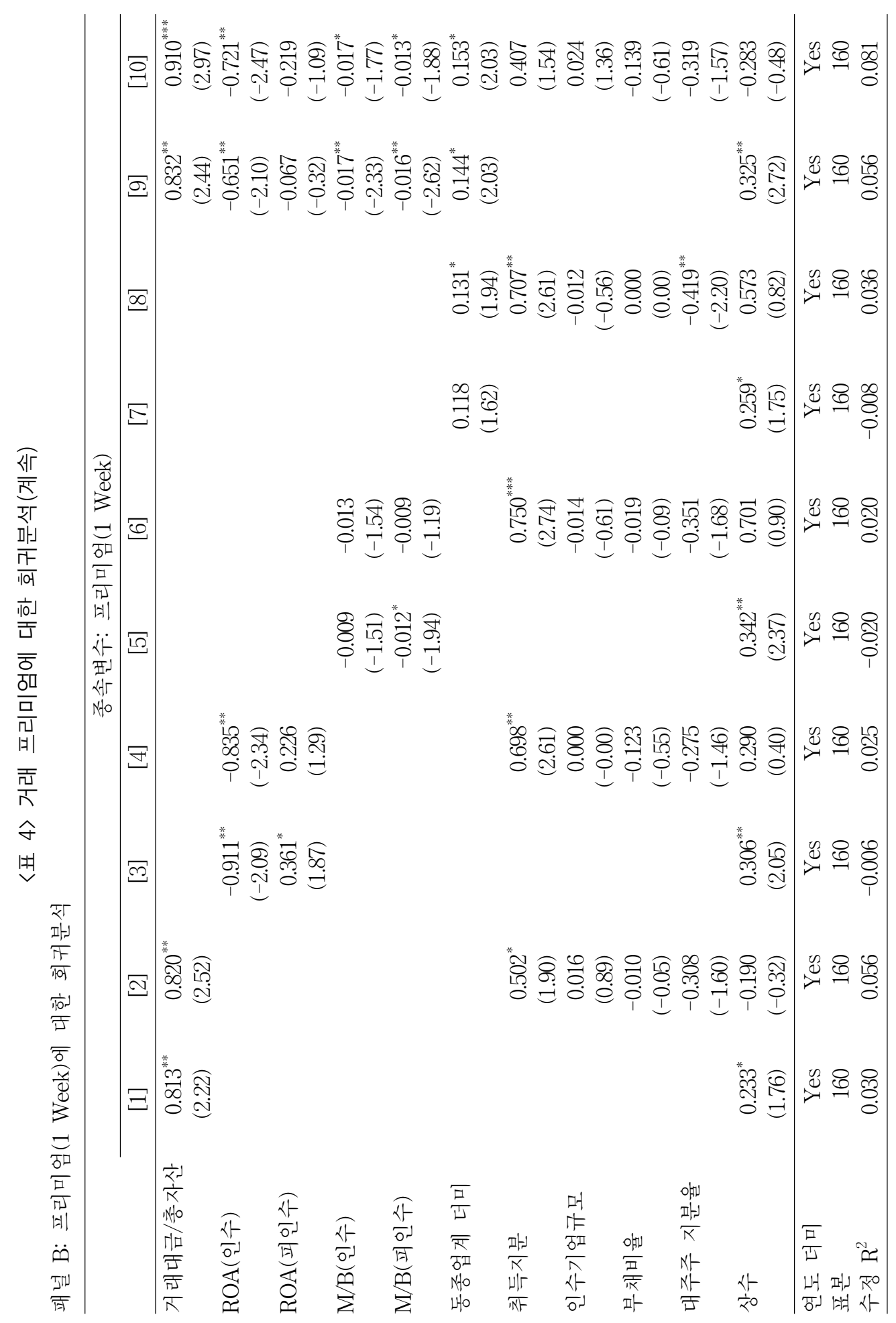


한국증권학회지 제49권 5 호 (2020)

\subsection{3 프리미엄금액을 종속변수로 사용한 회귀분석}

위에 보고된 분석에서 거래 프리미엄(즉, 프리미엄(1 Day)과 프리미엄(1 Week))은 주당 거래가격과 피인수기업의 주가 간의 차이를 나타내지만, 거래 프리미엄의 규모를 금액으로 나타내는 것은 아니므로 인수기업이 프리미엄으로 얼마나 큰 금액을 지급하는가를 측정하는데 한계가 있다. 대체적인 방법으로 거래 프리미엄을 측정하기 위해 프리미엄금액(1 Day)과 프리미엄금액(1 Week)을 설정하였으며 <부록 3>에 제시되었듯이 각각 “(거래대금-(공시 1일전 종가x취득주식 수))/인수기업의 직전년도 총자산”과 “(거래대금-(공시 1 주전 종가x취득주식 수))/인수기업의 직전년도 총자산”으로 정의된다. <표 2>에 보고되었듯이 프리미엄금액(1 $\mathrm{Day})$ 과 프리미엄금액(1 Week)의 평균(중간값)은 각각 $0.7 \%(0 \%)$ 과 $0.7 \%(0 \%)$ 이며 표준편차는 $4.6 \%, 4.8 \%$ 이다.

$<$ 표 $5>$ 의 회귀분석 결과는 프리미엄금액을 종속변수로 설정한 회귀분석 결과를 보고하는데 대체적으로 <표 $4>$ 의 결과를 재확인 해준다. 패널 $\mathrm{A}$ 와 패널 $\mathrm{B}$ 의 종속변수는 각각 프리미엄금액(1 Day)과 프리미엄금액(1 Week)인데 두 패널 모두 거래대금/총자산은 양(+)의 계수값을 나타낸다. 이는 거래규모가 큰 거래일수록 프리미엄이 높음을 시사하긴 하지만, 프리미엄금액(종속변수)과 거래대금이 기계적으로 높은 상관관계를 갖기 때문에 발생하는 현상일 수도 있다. 한편 두 패널에서 $\mathrm{ROA}$ (인수)는 설명변수로 사용된 칼럼에서 - 패널 B의 칼럼 [9] [10]을 제외하고유의한 음(-)의 계수값을 나타내 영업실적이 높은(낮은) 인수기업일수록 프리미엄을 적게(높게) 지급한다는 관계가 재확인되었다. 영업성과를 반영하는 $\mathrm{M} / \mathrm{B}$ (인수)도 많은 칼럼에서 유의한 음(-)의 계수값을 나타내 이 관계에 추가적 증거를 얻을 수 있다.

그런데 <표 $5>$ 의 결과에서 대주주 지분율은 설명변수로 사용된 모든 칼럼에서 유의한 음(-)의 계수값을 나타내는데 이는 패널 $\mathrm{A}$ 와 패널 $\mathrm{B}$ 에 공통적으로 나타나는 현상이다. 이는 <표 $4>$ 에서 대주주 지분율의 계수값이 유의성이 없었던 것과는 대조적인 현상이다. 따라서 프리미엄을 프리미엄금액/총자산으로 계산할 경우 대주주 지분율이 높은 기업일수록 낮은 프리미엄을 지급하는 경향이 존재하는 것으로 보이며, 이는 다소 조심스럽지만, 대주주 지배력이 높은 기업일수록 인수거래시 높은 프리미엄을 지급하는 것을 꺼린다고 시사할 수도 있다.

\section{3 지분매입 거래의 공시 주가반응}

\subsection{1 공시 주가효과(CAR)의 평균과 중간값}

지분거래 공시에 대해 인수기업과 피인수기업의 주가가 어떤 반응을 나타내는가를 사건연구 (event study)를 통해 분석한다. <표 6>은 인수기업(패널 A)과 피인수기업(패널 B)의 누적초과 수익률(CAR)의 평균을 9 개의 윈도우에 대해 보고한다. 패널 $\mathrm{A}$ 에 보고된 인수기업의 $\mathrm{CAR}$ 은 보고된 모든 윈도우에서 평균과 중간값이 0에 가까운 수치를 나타내며 통계적 유의성이 나타나지 않았다. 따라서 인수기업의 경우 지분거래 공시가 주가에 긍정 또는 부정적인 효과를 나타내는 것으로는 보이지 않는다. 
Premiums and Stock Price Responses in Equity-Stake Purchase Deals in Korea's Stock Market

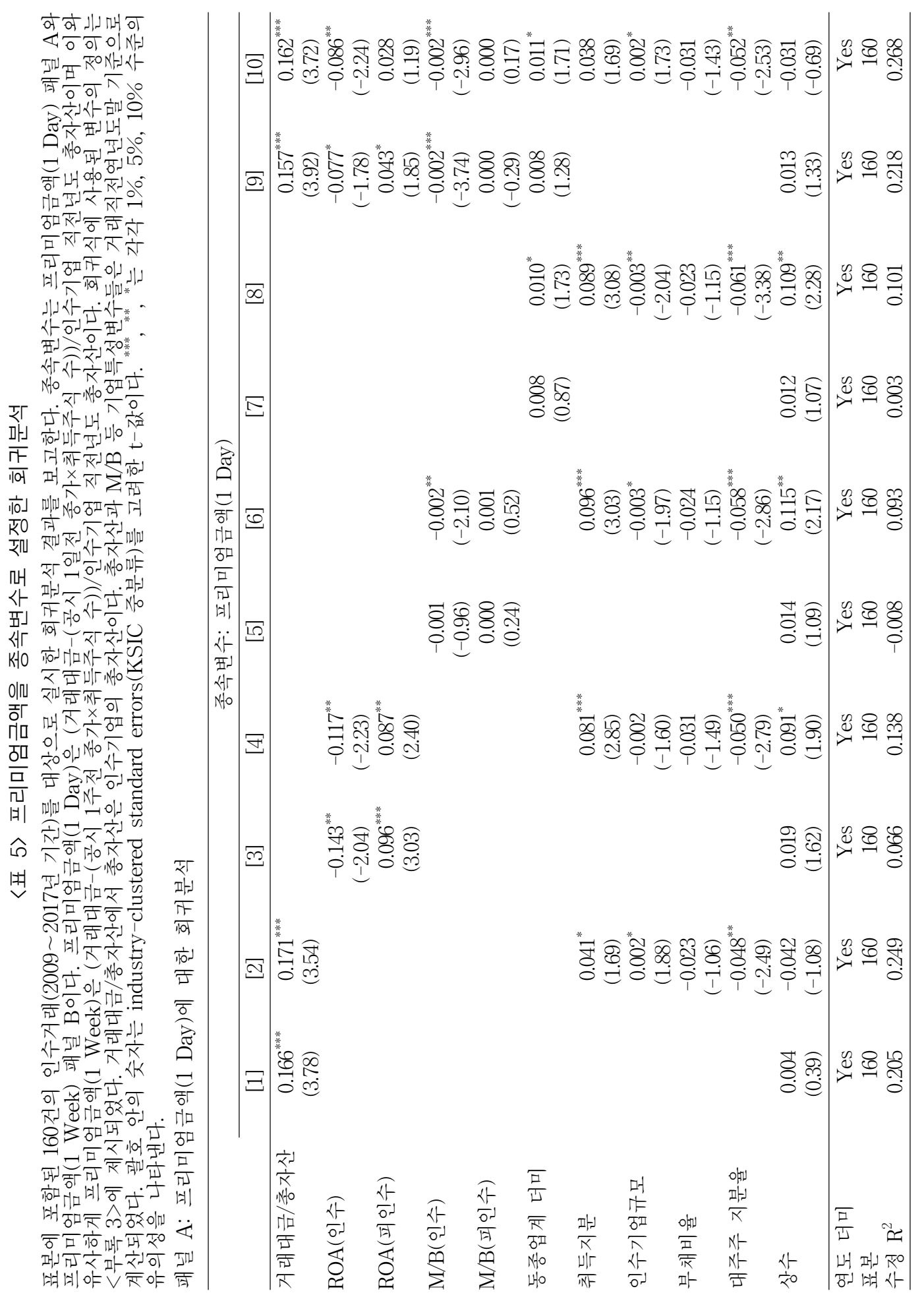




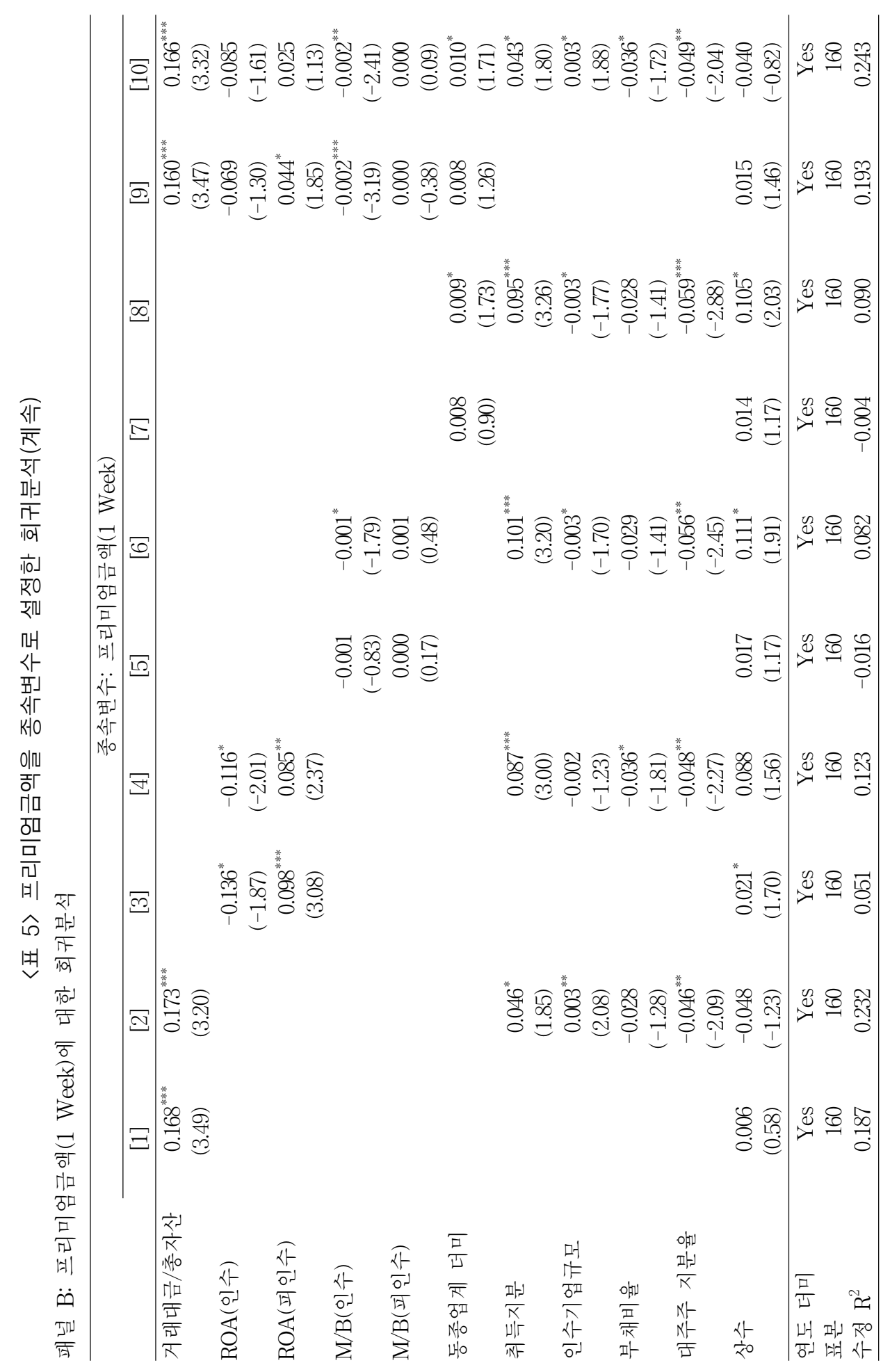


Premiums and Stock Price Responses in Equity-Stake Purchase Deals in Korea's Stock Market

〈표 6〉 지분거래 공시에 대한 누적초과수익률(CAR)의 요약통계량

표본에 포함된 160건의 인수거래(2009 2017년 기간)를 대상으로 본문 식 (3) 식 (4)를 따라 계산한 누적초과수익률(CAR)의 요약통계량을 보고한다. 이 요약통계량은 $\mathrm{CAR}$ 수치를 분포의 상하 $1 \%$ 수준에서 winsorizing 한 후 계산되었다. 평균과 중간값 수치의 ***, ** *는 각각 $1 \%, 5 \%, 10 \%$ 수준의 통계적 유의성을 의미한다.

패널 $\mathrm{A}:$ 인수기업의 주가반응

\begin{tabular}{lcrrccccc}
\hline & 표본 & 평균 & 중간값 & 표준편차 & 최소값 & $\mathrm{Q} 1$ & $\mathrm{Q} 3$ & 최대값 \\
\hline $\mathrm{CAR}(-10,10)$ & 160 & -0.003 & 0.007 & 0.179 & -0.464 & -0.098 & 0.093 & 0.544 \\
$\mathrm{CAR}(-10,5)$ & 160 & 0.000 & 0.005 & 0.143 & -0.371 & -0.079 & 0.059 & 0.411 \\
$\mathrm{CAR}(-10,2)$ & 160 & 0.010 & 0.011 & 0.121 & -0.253 & -0.053 & 0.064 & 0.383 \\
$\mathrm{CAR}(-5,10)$ & 160 & -0.011 & 0.003 & 0.150 & -0.396 & -0.095 & 0.062 & 0.328 \\
$\mathrm{CAR}(-5,5)$ & 160 & -0.003 & 0.006 & 0.118 & -0.303 & -0.069 & 0.059 & 0.318 \\
$\mathrm{CAR}(-5,2)$ & 160 & 0.005 & -0.001 & 0.094 & -0.188 & -0.054 & 0.052 & 0.278 \\
$\mathrm{CAR}(-2,10)$ & 160 & -0.009 & 0.008 & 0.135 & -0.393 & -0.065 & 0.054 & 0.311 \\
$\mathrm{CAR}(-2,5)$ & 160 & -0.002 & 0.004 & 0.100 & -0.304 & -0.050 & 0.046 & 0.276 \\
$\mathrm{CAR}(-2,2)$ & 160 & 0.008 & 0.005 & 0.071 & -0.153 & -0.030 & 0.045 & 0.207 \\
\hline
\end{tabular}

패널 B: 피인수기업의 주가반응

\begin{tabular}{lllrccccc}
\hline & 표본 & 평균 & 중간값 & 표준편차 & 최소값 & $\mathrm{Q} 1$ & $\mathrm{Q} 3$ & 최대값 \\
\hline $\mathrm{CAR}(-10,10)$ & 160 & $0.029^{*}$ & -0.012 & 0.199 & -0.343 & -0.086 & 0.112 & 0.678 \\
$\mathrm{CAR}(-10,5)$ & 160 & 0.019 & 0.008 & 0.155 & -0.301 & -0.084 & 0.093 & 0.414 \\
$\mathrm{CAR}(-10,2)$ & 160 & $0.021^{*}$ & 0.014 & 0.139 & -0.257 & -0.065 & 0.096 & 0.421 \\
$\mathrm{CAR}(-5,10)$ & 160 & $0.035^{* *}$ & 0.011 & 0.187 & -0.327 & -0.064 & 0.098 & 0.695 \\
$\mathrm{CAR}(-5,5)$ & 160 & $0.025^{* *}$ & 0.008 & 0.149 & -0.320 & -0.061 & 0.092 & 0.458 \\
$\mathrm{CAR}(-5,2)$ & 160 & $0.026^{* * *}$ & $0.005^{* *}$ & 0.124 & -0.247 & -0.043 & 0.072 & 0.383 \\
$\mathrm{CAR}(-2,10)$ & 160 & $0.024^{*}$ & 0.002 & 0.186 & -0.353 & -0.072 & 0.077 & 0.694 \\
$\mathrm{CAR}(-2,5)$ & 160 & 0.017 & -0.005 & 0.146 & -0.256 & -0.060 & 0.072 & 0.496 \\
$\mathrm{CAR}(-2,2)$ & 160 & $0.016^{*}$ & 0.009 & 0.112 & -0.235 & -0.048 & 0.059 & 0.385 \\
\hline
\end{tabular}

한편 패널 $\mathrm{B}$ 에 보고된 피인수기업의 $\mathrm{CAR}$ 의 경우 평균이 $1.6 \%-3.5 \%$ 의 양의 값을 나타내며 통계적으로 유의하다. 하지만, 중간값 기준으로는 보고된 모든 윈도우에서 $\mathrm{CAR}(-5,2)$ 을 제외하면 유의성이 없었다. 따라서 피인수기업의 경우 지분거래 공시가 평균값 기준으로 긍정적인 효과를 나타내는 것으로 보인다. ${ }^{14)}$

<그림 2>는 인수기업에 비해 피인수기업이 긍정적인 공시 주가반응을 나타낸다는 관측을 그래프로 보고한다. 인수기업의 경우 CAR의 평균값이 $(-10,-10)$ 에서 $(-10,10)$ 에 이르는 모든 윈도우에서 0 에 가까운 반면, 피인수기업의 경우 $\mathrm{CAR}$ 의 평균값이 $(-10,-5)$ 윈도우를 기점으로 양의 값을 나타내고 있다. 결론적으로 지분거래에 따른 공시 주가효과는 인수기업 주주들은 누리지 못하는 반면 피인수기업의 주주들이 누리는 것으로 해석할 수 있다.

14) 표본 피인수기업 중 공시 주가반응이 특히 긍정적인 기업은 홈캐스트-디엠티(2016년), 제이비어뮤즈 먼트-엠제이비(2013년), 다날-바른손이앤에이(2015년)였다. 이들의 $\operatorname{CAR}(-2,2)$ 값은 각각 0.567 , $0.385,0.342$ 였으며 winsorization 실시 후 홈캐스트-디엠티의 값은 0.385 로 조정되었다. 
〈그림 2〉 지분매입 인수거래의 공시 주가반응

표본에 포함된 160건의 인수거래(2009 2017년 기간)에 대해 초과수익률(AR)과 누적초과수익률(CAR)의 평균을 $(-10,+10)$ 기간에 대해 계산하여 보고한다. 패널 $\mathrm{A}$ 와 패널 $\mathrm{B}$ 는 각각 인수기업과 피인수기업에 대한 분석 결과이다.

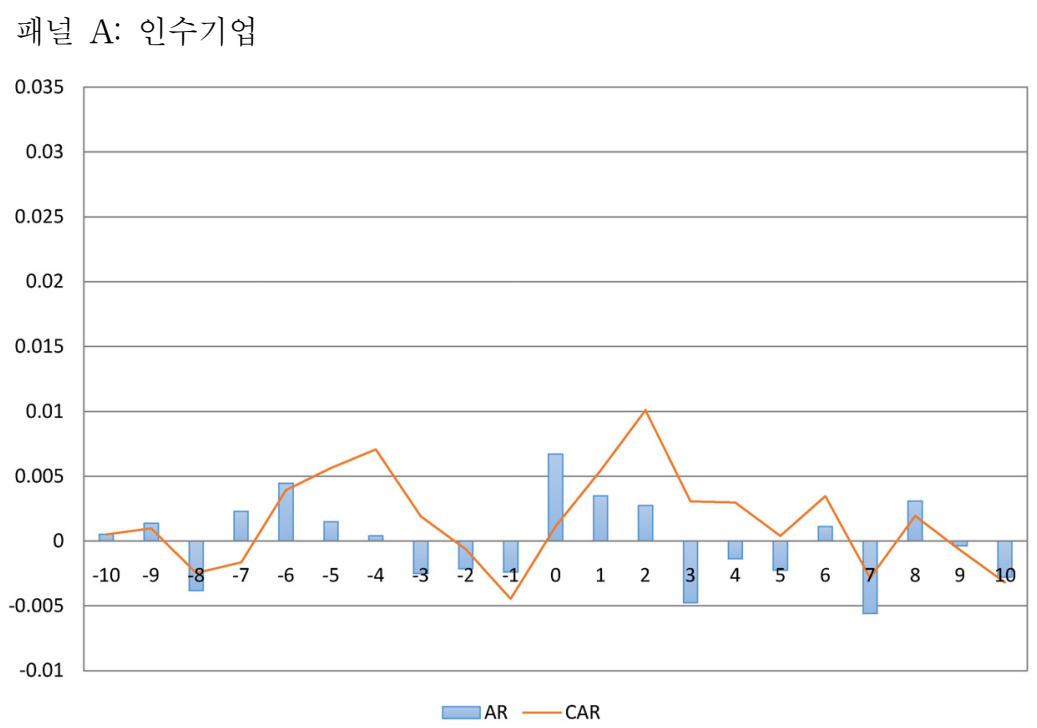

패널 B: 피인수기업

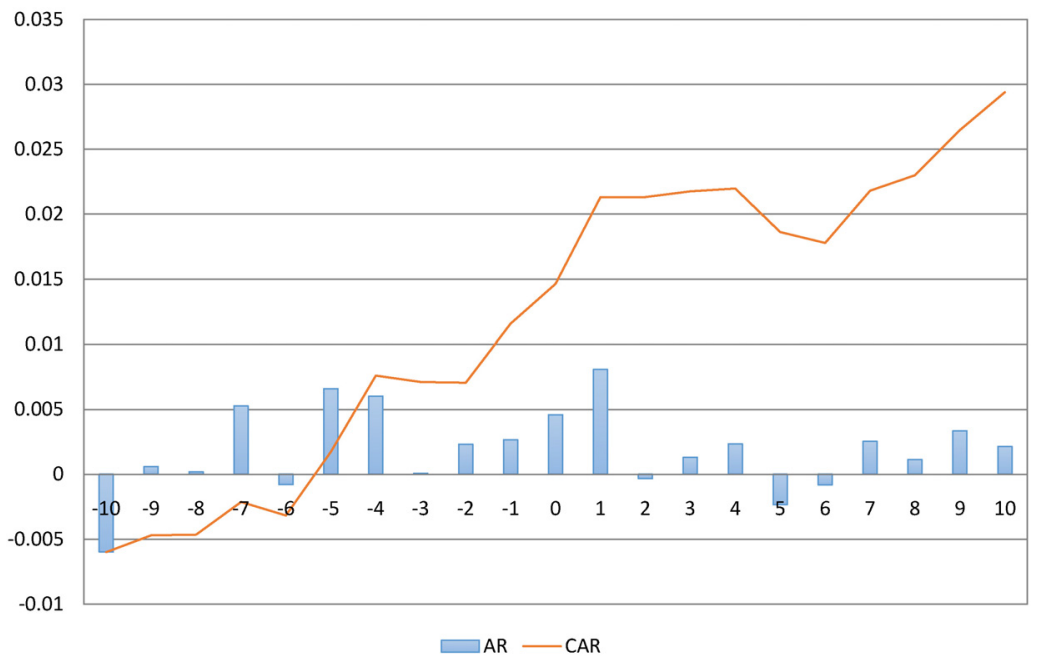

\subsection{2 거래 프리미엄과 공시 주가효과(CAR) 간의 관계}

<표 7>에서는 거래 프리미엄의 크기에 따라 인수기업과 피인수기업의 주가반응 크기가 변화하는지를 $\operatorname{CAR}(-2,1), \operatorname{CAR}(-2,2), \operatorname{CAR}(-2,3)$ 을 이용해 분석한다. 분석을 위해 표본에 포함된 지분거래를 거래 프리미엄(1 Week) 기준으로 오분위 하위집단(즉, Quintile)을 생성한 후 이 하위집단의 $\mathrm{CAR}$ 의 평균과 중간값을 분석한다. 
Premiums and Stock Price Responses in Equity-Stake Purchase Deals in Korea's Stock Market

패널 $\mathrm{A}$ 는 거래 프리미엄과 인수기업의 주가반응 간의 관계를 보고하는데 최하위그룹인 Quintile 1을 비롯한 Quintile 2, Quintile 3, Quintile 4에서는 CAR의 평균과 중간값의 유의성이 없는 반면 최상위 그룹인 Quintile 5의 경우 $\operatorname{CAR}(-2,1)$ 의 평균에서는 유의한 양의 값을 나타내었다. 또한 마지막 행에 보고되었듯이 $\operatorname{CAR}(-2,1)$ 과 $\mathrm{CAR}(-2,2)$ 의 경우 최상위그룹과 최하위그룹 간의 차이(Quintile 5-Quintile 1)는 평균 또는 중간값에서 유의한 값을 나타 내었다. 이는 인수기업의 주가반응은 거래 프리미엄이 높을수록 긍정적이라는 증거로 해석할 수 있다.

패널 $\mathrm{B}$ 는 거래 프리미엄과 피인수기업의 주가반응 간의 관계를 분석하는데, 마지막 행에서 보고되었듯이 최상위그룹과 최하위그룹 간의 CAR 차이(Quintile 5 - Quintile 1)는 양의 값을 가지긴 하지만 평균과 중간값에 대한 차이의 유의성은 없었다. 따라서 거래 프리미엄이 높다고 해서 피인수기업의 주가반응이 긍정적인 패턴은 유의성이 없다. 결론적으로 거래 프리미엄이 높은 지분거래에서는 인수기업의 공시 주가효과는 상대적으로 긍정적인 반면, 피인수기업의 경우에는 이 같은 결과가 나타나지 않았다.

\section{〈표 7〉 거래 프리미엄의 크기와 CAR}

표본에 포함된 160건의 인수거래(2009 2017년 기간)를 거래 프리미엄(1 Week)의 값에 따라 오분위(즉, Quintile) 하위그룹을 설정한 후 (Quintile 1의 프리미엄이 가장 낮고, Quintile 5 가 가장 높음) 각 하위그룹에 대해 $\mathrm{CAR}(-2,1), \mathrm{CAR}(-2,2), \mathrm{CAR}(-2,3)$ 으로 계산한 공시 주가반응의 평균과 중간값을 보고한다. 패널 $\mathrm{A}$ 와 $\mathrm{B}$ 는 각각 인수기업과 피인수기업의 주가반응을 보고한다. 마지막 단인 "Quint. 5 - Quint. 1 ”은 두 Quintile 그룹의 평균과 중간값 차이에 대한 유의성을 보고한다. ${ }^{* * *},{ }^{* *}$, "는 각각 $1 \%, 5 \%, 10 \%$ 수준의 통계적 유의성을 의미한다.

패널 $\mathrm{A}$ : 거래 프리미엄과 인수기업 주가반응

\begin{tabular}{|c|c|c|c|c|c|c|}
\hline \multirow{2}{*}{ 프리미엄(1 Week) } & \multicolumn{2}{|c|}{$\operatorname{CAR}(-2,1)$} & \multicolumn{2}{|c|}{$\operatorname{CAR}(-2,2)$} & \multicolumn{2}{|c|}{$\operatorname{CAR}(-2,3)$} \\
\hline & 평균 & 중간값 & 평균 & 중간값 & 평균 & 중간값 \\
\hline Quintile 1 (low) & -0.007 & 0.005 & -0.012 & -0.005 & -0.007 & -0.003 \\
\hline Quintile 2 & 0.006 & -0.002 & 0.013 & 0.008 & 0.004 & 0.001 \\
\hline Quintile 3 & 0.004 & 0.011 & 0.008 & 0.013 & 0.006 & 0.014 \\
\hline Quintile 4 & 0.005 & 0.000 & 0.009 & 0.007 & 0.002 & 0.010 \\
\hline Quintile 5 (high) & $0.022^{*}$ & 0.012 & 0.021 & 0.007 & 0.007 & 0.001 \\
\hline Quint. 5 - Quint. 1 & $0.030^{*}$ & 0.007 & $0.033^{*}$ & $0.012^{*}$ & 0.014 & 0.005 \\
\hline
\end{tabular}

패널 $\mathrm{B}$ : 거래 프리미엄과 피인수기업 주가반응

\begin{tabular}{lllllllrr}
\hline \multirow{2}{*}{ 프리미엄 (1 Week) } & \multicolumn{2}{c}{$\mathrm{CAR}(-2,1)$} & & \multicolumn{2}{c}{$\mathrm{CAR}(-2,2)$} & & \multicolumn{2}{c}{$\mathrm{CAR}(-2,3)$} \\
\cline { 2 - 4 } \cline { 7 - 8 } & 평균 & 중간값 & & 평균 & 중간값 & & 평균 & 중간값 \\
\hline Quintile 1 (low) & 0.004 & 0.010 & & -0.004 & 0.019 & & 0.005 & 0.023 \\
Quintile 2 & 0.011 & 0.001 & & 0.022 & 0.008 & & 0.013 & 0.003 \\
Quintile 3 & 0.010 & 0.002 & & 0.011 & 0.001 & & 0.017 & -0.005 \\
Quintile 4 & $0.024^{*}$ & 0.028 & & 0.022 & 0.007 & & 0.022 & 0.019 \\
Quintile 5 (high) & 0.029 & 0.015 & & 0.028 & 0.021 & & 0.026 & 0.008 \\
Quint. 5 - Quint. 1 & 0.024 & 0.006 & & 0.033 & 0.002 & & 0.020 & -0.015 \\
\hline
\end{tabular}




\subsection{3 인수기업· 피인수기업의 주가반응(CAR)에 대한 횡단면 회귀분석}

$<$ 표 8>에서는 인수기업과 피인수기업의 공시 주가반응 $(\operatorname{CAR}(-2,2))$ 에 영향을 미치는 요인을 분석하는 회귀분석을 실시한다. 패널 $\mathrm{A}$ 에 보고된 회귀식의 종속변수는 인수기업의 $\mathrm{CAR}(-2$, 2)인데, 설명변수 중 하나인 거래 프리미엄은 프리미엄(1 Week)을 사용하였으며 ROA(피인수)를 제외한 모든 기업특성변수는 인수기업에 대해 계산되었다. 칼럼 [1]과 [6]에 보고된 프리미엄(1

〈표 8〉 인수기업과 피인수기업의 $\operatorname{CAR}(-2,2)$ 에 대한 횡단면 회귀분석

표본에 포함된 160 건의 인수거래(2009-2017년 기간)를 대상으로 인수기업의 $\operatorname{CAR}(-2,2)$ 패널 $\mathrm{A}$ 와 피인수기업의 $\mathrm{CAR}(-2,2)$ 패널 $\mathrm{B}$ 를 종속변수로 사용한 회귀분석 결과를 보고한다. 회귀식에 사용된 변수의 정의는 <부록 $3>$ 에 제시되었다. 패널 $\mathrm{A}$ 의 기업특질변수는 $\mathrm{ROA}$ (피인수)를 제외하면 모두 인수기업 특질이며 패널 $\mathrm{B}$ 의 기업특질변수는 $\mathrm{ROA}$ (인수)를 제외하면 모두 피인수기업 특질이다. 예들 들어 거래대금/총자산의 총자산은 패널 $\mathrm{A}$ 의 경우 인수기업 총자산이며 패널 $\mathrm{B}$ 의 경우 피인수기업 총자산이다. 총자산과 $\mathrm{M} / \mathrm{B}$ 등 기업특성변수들은 거래직전연년도말 기준으로 계산되었다. 회귀계수 값 아래에 괄호 안의 숫자는 industry-clustered standard errors(KSIC 중분류)를 고려한 t-값이며, ${ }^{* * *},{ }^{* *},{ }^{*}$ 는 각각 $1 \%, 5 \%, 10 \%$ 수준의 통계적 유의성을 의미한다.

패널 $\mathrm{A}$ : 인수기업의 주가반응에 대한 회귀분석

\begin{tabular}{|c|c|c|c|c|c|c|}
\hline & \multicolumn{6}{|c|}{ 종속변수: 인수기업 $\operatorname{CAR}(-2,2)$} \\
\hline & [1] & [2] & [3] & {$[4]$} & [5] & [6] \\
\hline 프리미엄(1 Week) & $\begin{array}{c}0.027^{*} \\
(1.74)\end{array}$ & & & & & $\begin{array}{c}0.028^{*} \\
(1.85)\end{array}$ \\
\hline 취득지분 & & $\begin{array}{l}-0.013 \\
(-0.36)\end{array}$ & & & & $\begin{array}{l}-0.023 \\
(-0.53)\end{array}$ \\
\hline 거래대금/총자산 & & & $\begin{array}{l}-0.010 \\
(-0.28)\end{array}$ & & & $\begin{array}{l}-0.054 \\
(-1.15)\end{array}$ \\
\hline $\mathrm{ROA}$ (인수) & & & & $\begin{array}{l}-0.056 \\
(-0.55)\end{array}$ & & $\begin{array}{l}-0.039 \\
(-0.24)\end{array}$ \\
\hline ROA(피인수) & & & & $\begin{array}{c}0.080^{*} \\
(1.77)\end{array}$ & & $\begin{array}{c}0.100^{*} \\
(1.84)\end{array}$ \\
\hline 동종업계 더미 & & & & & $\begin{array}{c}0.002 \\
(0.21)\end{array}$ & $\begin{array}{c}0.001 \\
(0.09)\end{array}$ \\
\hline 인수기업규모 & & & & & & $\begin{array}{l}-0.001 \\
(-0.24)\end{array}$ \\
\hline $\mathrm{M} / \mathrm{B}$ & & & & & & $\begin{array}{l}-0.001 \\
(-0.51)\end{array}$ \\
\hline 부채비율 & & & & & & $\begin{array}{l}-0.016 \\
(-0.36)\end{array}$ \\
\hline 대주주 지분율 & & & & & & $\begin{array}{l}-0.050 \\
(-1.08)\end{array}$ \\
\hline 상수 & $\begin{array}{r}-0.008 \\
(-0.46) \\
\end{array}$ & $\begin{array}{r}0.002 \\
(0.08) \\
\end{array}$ & $\begin{array}{r}0.000 \\
(-0.01) \\
\end{array}$ & $\begin{array}{r}0.003 \\
(0.10) \\
\end{array}$ & $\begin{array}{l}-0.001 \\
(-0.05) \\
\end{array}$ & $\begin{array}{r}0.044 \\
(0.51) \\
\end{array}$ \\
\hline 연도 더미 & Yes & Yes & Yes & Yes & Yes & Yes \\
\hline 표본 & 160 & 160 & 160 & 160 & 160 & 160 \\
\hline 수정 $\mathrm{R}^{2}$ & -0.016 & -0.044 & -0.045 & -0.039 & -0.045 & -0.039 \\
\hline
\end{tabular}


Premiums and Stock Price Responses in Equity-Stake Purchase Deals in Korea's Stock Market

〈표 8〉 인수기업과 피인수기업의 $\operatorname{CAR}(-2,2)$ 에 대한 횡단면 회귀분석(계속) 패널 B: 피인수기업의 주가반응에 대한 회귀분석

\begin{tabular}{|c|c|c|c|c|c|c|}
\hline & \multicolumn{6}{|c|}{ 종속변수: 피인수기업 $\mathrm{CAR}(-2,2)$} \\
\hline & {$[1]$} & {$[2]$} & {$[3]$} & [4] & [5] & [6] \\
\hline 프리미엄(1 Week) & $\begin{array}{c}0.028 \\
(1.01)\end{array}$ & & & & & $\begin{array}{c}0.016 \\
(0.71)\end{array}$ \\
\hline 취득지분 & & $\begin{array}{l}0.106 \\
(1.56)\end{array}$ & & & & $\begin{array}{l}0.063 \\
(0.72)\end{array}$ \\
\hline 거래대금/총자산 & & & $\begin{array}{l}0.103^{* * *} \\
(2.82)\end{array}$ & & & $\begin{array}{l}0.061 \\
(1.24)\end{array}$ \\
\hline $\mathrm{ROA}$ (인수) & & & & $\begin{array}{l}0.005 \\
(0.03)\end{array}$ & & $\begin{array}{l}-0.004 \\
(-0.03)\end{array}$ \\
\hline ROA(피인수) & & & & $\begin{array}{l}-0.027 \\
(-0.32)\end{array}$ & & $\begin{array}{l}-0.041 \\
(-0.37)\end{array}$ \\
\hline 동종업계 더미 & & & & & $\begin{array}{r}-0.014 \\
(-0.82)\end{array}$ & $\begin{array}{l}-0.014 \\
(-0.79)\end{array}$ \\
\hline 피인수기업규모 & & & & & & $\begin{array}{l}-0.006 \\
(-0.53)\end{array}$ \\
\hline $\mathrm{M} / \mathrm{B}$ & & & & & & $\begin{array}{l}0.000 \\
(0.09)\end{array}$ \\
\hline 부채비율 & & & & & & $\begin{array}{l}-0.015 \\
(-0.24)\end{array}$ \\
\hline 대주주 지분율 & & & & & & $\begin{array}{r}0.042 \\
(0.65)\end{array}$ \\
\hline 상수 & $\begin{array}{r}0.042 \\
(1.25)\end{array}$ & $\begin{array}{r}0.029 \\
(0.76)\end{array}$ & $\begin{array}{l}0.037 \\
(1.16)\end{array}$ & $\begin{array}{r}0.049 \\
(1.52)\end{array}$ & $\begin{array}{r}0.052 \\
(1.68)\end{array}$ & $\begin{array}{r}0.162 \\
(0.60)\end{array}$ \\
\hline 연도 더미 & Yes & Yes & Yes & Yes & Yes & Yes \\
\hline 표본 & 160 & 160 & 160 & 160 & 160 & 160 \\
\hline 수정 $\mathrm{R}^{2}$ & -0.025 & -0.020 & 0.002 & -0.044 & -0.034 & -0.043 \\
\hline
\end{tabular}

Week)의 계수는 각각 0.027 과 0.028 로 통계적으로 유의한 양(+)의 값을 나타냈다.15) 또한 칼럼 [4]와 [6]에 보고된 바와 같이 $\mathrm{ROA}$ (피인수)의 계수 또한 유의한 양(+)의 값을 나타내었다. 따라서 인수기업의 경우 거래 프리미엄이 높은 거래일수록 또한 피인수기업의 영업수익성이 높을수록 긍정적인 공시 주가반응을 나타내는 것으로 보인다. 한편 다른 설명변수들은 유의한 계수값을 나타내지 않았다. 특히 거래대금/총자산, 취득지분, $\mathrm{ROA}$ (인수) 등의 계수값은 유의성이 없었으며 따라서 거래규모가 크거나 취득지분이 크거나 인수기업의 영업성과가 좋다고 해서 인수기업의 공시 주가반응이 달라지지는 않는 것으로 보인다.

패널 $\mathrm{B}$ 에서는 피인수기업의 $\mathrm{CAR}(-2,2)$ 을 회귀식의 종속변수로 설정하였는데, $\mathrm{ROA}$ (인수)를

15) 표에 보고하지는 않았지만, 프리미엄(1 Week) 대신에 프리미엄(1 Day)을 사용하더라도 패널 A와 패널 $\mathrm{B}$ 모두 질적으로 동일한 결과를 발견하였다. 
한국증권학회지 제49권 5 호 (2020)

제외한 모든 기업특성변수는 피인수기업에 대해 계산되었다. 칼럼 [3]에 따르면 거래대금/ 총자산의 계수는 유의한 양(+)의 값을 나타낸다. 하지만 칼럼 [6]에 따르면 다른 설명변수들을 추가할 경우 이 변수의 유의성이 사라진다. 또한 회귀식에 포함된 다른 설명변수들은 모두 계수값의 유의성이 없었다. 따라서 고려된 거래특성변수와 기업특성변수 중에는 피인수기업의 공시 주가반응에 유의적인 영향을 미치는 변수는 없는 것으로 판단된다. 특히 프리미엄(1 Week), 취득지분, $\mathrm{ROA}$ (인수), $\mathrm{ROA}$ (피인수) 모두 계수값의 유의성이 없기 때문에, 거래 프리미엄이 높거나, 취득지분이 크거나, 인수·피인수기업의 영업성과의 높고 낮음에 따라 피인수기업의 주가반응이 달라지지는 않는 것으로 보인다.

회귀분석 결과를 요약하자면, 인수기업의 경우 거래 프리미엄이 높은 거래일수록 주가반응이 좋은 것으로 나타났는데, 이는 거래 프리미엄이 높을 경우 과잉지급에 대한 우려에 의해 주가반응이 부정적일 것이라는 예측은 지지되지 않는 결과이다.16) 또한 영업성과가 우수한 (열악한) 피인수기업의 지분을 취득하는 경우 주가반응이 좋은(나쁜) 것으로 나타났다. 피인수 기업의 경우(고려된 변수 중에는) 주가반응에 유의적인 영향을 미치는 요인을 발견할 수 없었다.

\section{4 추가분석: 주요 하부집단 간 거래 프리미엄과 주가반응 차이 분석}

<표 9>에서는 인수기업과 피인수기업이 대규모 기업집단 소속 기업인가 등의 여부에 따라 거래 프리미엄의 크기가 달라지는지를 분석하였다. 패널 $\mathrm{A}$ 는 인수기업이 대규모 기업집단 소속인가에 따라 표본을 분할하였다. 프리미엄(1 Day)의 경우 평균과 중간값에서 모두 대규모 집단소속 vs. Others 간 유의적인 차이가 나타나지 않았다. 프리미엄(1 Week)의 경우 평균에서 두 집단 간 유의적 차이가 없었으나 중간값에서는 대규모 기업집단의 프리미엄(0.039)이 Others의 프리미엄 $(-0.014)$ 보다 유의하게 높게 나타났다. 한편 패널 B에서는 피인수기업이 대규모 기업 집단 소속인가에 따라 표본을 분할하였는데, 프리미엄(1 Day)과 프리미엄(1 Week) 모두 평균과 중간값에서 대규모집단소속 vs. Others 간 유의적인 차이가 나타나지 않았다. 패널 C에서는 지분거래의 인수·피인수기업이 모두 동일기업집단 소속인가(즉, 동일 기업집단 내에서의 인수 거래인가)에 따라 표본을 분할하였다. 이 역시 프리미엄(1 Day)과 프리미엄(1 Week) 모두 평균과 중간값에서 동일기업집단 내 인수거래 vs. Others 간 유의적인 차이가 나타나지 않았다. 따라서 인수기업과 피인수기업이 기업집단 소속인가 여부 또는 인수거래가 동일기업집단 내 거래인가 여부는 거래 프리미엄에 대체로 유의한 영향을 미치지 않는 것으로 판단된다. 마지막으로 패널 $\mathrm{D}$ 에서는 지분거래가 인수기업이 피인수기업의 지분을 최초로 매입한 신규매입인지 아니면 추가매입인가에 따라 표본을 분할하였는데 프리미엄(1 Day)과 프리미엄(1 Week) 모두 평균과 중간값에서 유의적인 차이가 나타나지 않았다.

16) 본 논문에 표로 보고하지 않았지만 프리미엄(1 Week) 대신 프리미엄금액(1 Week)을 설명변수로 사용하여도 프리미엄 계수의 유의성이 유지되었다. 이 관측에 대해 "높은 프리미엄은 인수기업의 자신감을 시장에 시그널"하기 때문에 인수기업의 주가반응이 좋다는 해석을 조심스럽게 해 볼 수 있다. 
Premiums and Stock Price Responses in Equity-Stake Purchase Deals in Korea's Stock Market

〈표 9〉 주요 하부집단 간 거래 프리미엄의 크기 비교

패널 $\mathrm{A}$ 는 인수기업이 공정거래위원회에 등록된 대규모 기업집단에 소속되어 있는가에 따라 표본을 두 그룹으로 분할 한 후 프리미엄(1 Day)과 프리미엄(1 Week)의 평균과 중간값을 비교한다. 패널 $\mathrm{B}$ 는 피인수기업을 대상으로 대규모 기업집단 소속 여부를 식별한 후 표본을 분할하였다. 패널 $\mathrm{C}$ 는 인수기업과 피인수기업이 모두 동일기업집단에 속한 경우와 아닌 경우로 표본을 분할하였다. 동일기업집단 소속 여부는 저자들의 수작업으로 확인하였다. 패널 $\mathrm{D}$ 는 지분거래가 인수기업이 피인수기업의 지분을 최초로 매입한 신규매입인지 아니면 추가매입인가에 따라 표본을 분할하였다. 평균과 중간값의 차이 검증은 각각 t-test와 Wilcoxon's z-test이며, ${ }^{* * *}{ }^{* *}{ }^{*}$ 는 각각 $1 \%, 5 \%, 10 \%$ 수준의 통계적 유의성을 의미한다. 패널 A: 인수기업이 대규모 기업집단 소속 vs. Others

\begin{tabular}{|c|c|c|c|c|c|c|c|c|}
\hline & \multicolumn{3}{|c|}{ 대규모 기업집단 소속 } & \multicolumn{3}{|c|}{ Others } & \multicolumn{2}{|c|}{ 차이 검증 } \\
\hline & 건수 & 평균 & 중간값 & 건수 & 평균 & 중간값 & 평균 & 중간값 \\
\hline 프리미엄(1 Day) & 38 & 0.101 & 0.001 & 122 & 0.078 & -0.006 & 0.023 & 0.008 \\
\hline 프리미엄(1 Week) & 38 & 0.148 & 0.039 & 122 & 0.094 & -0.014 & 0.054 & $0.053^{* *}$ \\
\hline
\end{tabular}

패널 B: 피인수기업이 대규모 기업집단 소속 vs. Others

\begin{tabular}{|c|c|c|c|c|c|c|c|c|}
\hline & \multicolumn{3}{|c|}{ 대규모 기업집단 소속 } & \multicolumn{3}{|c|}{ Others } & \multicolumn{2}{|c|}{ 차이 검증 } \\
\hline & 건수 & 평균 & 중간값 & 건수 & 평균 & 중간값 & 평균 & 중간값 \\
\hline 프리미엄(1 Day) & 20 & 0.099 & -0.001 & 140 & 0.081 & -0.002 & 0.017 & 0.001 \\
\hline 프리미엄(1 Week) & 20 & 0.129 & -0.003 & 140 & 0.103 & 0.011 & 0.026 & -0.014 \\
\hline
\end{tabular}

패널 C: 동일기업집단 소속 기업 간의 인수거래 vs. Others

\begin{tabular}{|c|c|c|c|c|c|c|c|c|}
\hline & \multicolumn{3}{|c|}{ 동일기업집단 내 인수거래 } & \multicolumn{3}{|c|}{ Others } & \multicolumn{2}{|c|}{ 차이 검증 } \\
\hline & 건수 & 평균 & 중간값 & 건수 & 평균 & 중간값 & 평균 & 중간값 \\
\hline 프리미엄(1 Day) & 42 & 0.063 & 0.000 & 118 & 0.091 & -0.012 & -0.028 & 0.012 \\
\hline 프리미엄(1 Week) & 42 & 0.077 & 0.000 & 118 & 0.117 & 0.012 & -0.040 & -0.012 \\
\hline
\end{tabular}

패널 D: 신규매입 vs. 추가매입

\begin{tabular}{|c|c|c|c|c|c|c|c|c|}
\hline & \multicolumn{3}{|c|}{ 신규매입 } & \multicolumn{3}{|c|}{ 추가매입 } & \multicolumn{2}{|c|}{ 차이 검증 } \\
\hline & 건수 & 평균 & 중간값 & 건수 & 평균 & 중간값 & 평균 & 중간값 \\
\hline 프리미엄(1 Day) & 101 & 0.104 & -0.003 & 59 & 0.049 & -0.002 & 0.055 & -0.001 \\
\hline 프리미엄(1 Week) & 101 & 0.129 & 0.011 & 59 & 0.068 & 0.000 & 0.061 & 0.011 \\
\hline
\end{tabular}

<표 $10>$ 에서는 인수기업과 피인수기업의 공시 주가반응 $\operatorname{CAR}(-2,2))$ 이 대규모 기업집단 소속 여부에 따라 달라지는지를 분석하였다. 패널 $\mathrm{A}$ 는 인수기업이 대규모 기업집단 소속인가에 따라 표본을 분할하였는데, 인수기업과 피인수기업의 주가반응 모두 평균과 중간값에서 대규모집단소속 vs. Others 간 유의적인 차이가 나타나지 않았다. 한편 패널 $\mathrm{B}$ 에서는 피인수 기업이 대규모 기업집단 소속인가에 따라 표본을 분할하였는데, 마찬가지로 인수기업과 피인수 기업의 주가반응 모두 평균과 중간값에서 대규모집단소속 vs. Others 간 유의적인 차이가 나타나지 않았다. 패널 $\mathrm{C}$ 에서는 동일 기업집단 내에서의 지분거래인가에 따라 표본을 분할 하였는데 이 역시 인수기업과 피인수기업의 주가반응 모두 하부집단 간 유의적인 차이가 나타나지 않았다. 마지막으로 패널 $\mathrm{D}$ 에서는 인수거래가 신규매입인지 추가매입인가에 따라 표본을 
한국증권학회지 제 49 권 5 호 (2020)

분할하였는데 인수기업과 피인수기업의 주가반응 모두 하부집단 간 유의적인 차이가 나타나지 않았다.

〈표 10〉 주요 하부집단 간 공시 주가반응(CAR)의 크기 비교

패널 $\mathrm{A}$ 는 인수기업이 공정거래위원회에 등록된 대규모 기업집단에 소속되어 있는가에 따라 표본을 두 그룹으로 분할 한 후 인수기업과 피인수기업의 $\operatorname{CAR}(-2,2)$ 을 비교한다. 패널 $\mathrm{B}$ 는 피인수기업이 대규모 기업집단 소속인가에 따라 표본을 분할하였다. 패널 $\mathrm{C}$ 는 인수기업과 피인수기업이 모두 동일기업집단에 속한 경우와 아닌 경우로 표본을 분할하였다. 동일기업집단 소속 여부는 저자들의 수작업으로 확인하였다. 패널 $\mathrm{D}$ 는 인수거래가 신규매입 또는 추가매입인가에 따라 표본을 분할하였다. 평균과 중간값의 차이

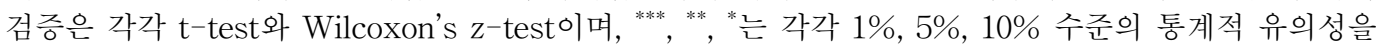
의미한다.

패널 A: 인수기업이 대규모 기업집단 소속 vs. Others

\begin{tabular}{|c|c|c|c|c|c|c|c|c|}
\hline & \multicolumn{3}{|c|}{ 대규모 기업집단 소속 } & \multicolumn{3}{|c|}{ Others } & \multicolumn{2}{|c|}{ 차이 검증 } \\
\hline & 건수 & 평균 & 중간값 & 건수 & 평균 & 중간값 & 평균 & 중간값 \\
\hline 인수기업 $\mathrm{CAR}(-2,2)$ & 38 & 0.016 & 0.015 & 122 & 0.005 & 0.003 & 0.011 & 0.012 \\
\hline 피인수기업 $\operatorname{CAR}(-2,2)$ & 38 & 0.017 & -0.003 & 122 & 0.015 & 0.013 & 0.002 & -0.015 \\
\hline
\end{tabular}

패널 B: 피인수기업이 대규모 기업집단 소속 vs. Others

\begin{tabular}{|c|c|c|c|c|c|c|c|c|}
\hline & \multicolumn{3}{|c|}{ 대규모 기업집단 소속 } & \multicolumn{3}{|c|}{ Others } & \multicolumn{2}{|c|}{ 차이 검증 } \\
\hline & 건수 & 평균 & 중간값 & 건수 & 평균 & 중간값 & 평균 & 중간값 \\
\hline 인수기업 $\mathrm{CAR}(-2,2)$ & 20 & 0.010 & 0.010 & 140 & 0.007 & 0.005 & 0.003 & 0.006 \\
\hline 피인수기업 $\operatorname{CAR}(-2,2)$ & 20 & 0.019 & 0.009 & 140 & 0.015 & 0.009 & 0.004 & 0.000 \\
\hline
\end{tabular}

패널 C: 동일기업집단 소속 기업 간의 인수거래 vs. Others

\begin{tabular}{|c|c|c|c|c|c|c|c|c|}
\hline & \multicolumn{3}{|c|}{ 동일기업집단 내 인수거래 } & \multicolumn{3}{|c|}{ Others } & \multicolumn{2}{|c|}{ 차이 검증 } \\
\hline & 건수 & 평균 & 중간값 & 건수 & 평균 & 중간값 & 평균 & 중간값 \\
\hline 인수기업 CAR(-2, 2) & 42 & 0.009 & 0.005 & 118 & 0.007 & 0.005 & 0.001 & 0.001 \\
\hline 피인수기업 $\operatorname{CAR}(-2,2)$ & 42 & -0.001 & -0.006 & 118 & 0.022 & 0.015 & -0.023 & -0.020 \\
\hline
\end{tabular}

패널 D: 신규매입 vs. 추가매입

\begin{tabular}{|c|c|c|c|c|c|c|c|c|}
\hline & \multicolumn{3}{|c|}{ 신규매입 } & \multicolumn{3}{|c|}{ 추가매입 } & \multicolumn{2}{|c|}{ 차이 검증 } \\
\hline & 건수 & 평균 & 중간값 & 건수 & 평균 & 중간값 & 평균 & 중간값 \\
\hline 인수기업 CAR(-2, 2) & 101 & 0.009 & 0.006 & 59 & 0.005 & 0.005 & 0.004 & 0.001 \\
\hline 피인수기업 $\operatorname{CAR}(-2,2)$ & 101 & 0.026 & 0.018 & 59 & -0.001 & -0.004 & 0.027 & 0.022 \\
\hline
\end{tabular}

\section{5. 결어 및 후속 연구}

본 연구는 지분매입 인수거래를 대상으로 거래 프리미엄의 규모, 분포, 결정요인과 인수·피인수 기업의 공시 주가반응을 분석하였으며 선행연구에서 보고되지 않은 분석 결과와 이론·제도적 시사점을 제시하였다. 하지만, 본 연구는 상장회사 간에 이루어진 지분매입 인수거래만을 대상으로 분석하였다는 한계가 있다. 향후 후속 연구에서는 인수기업과 피인수기업 중 한 회사 
Premiums and Stock Price Responses in Equity-Stake Purchase Deals in Korea's Stock Market

또는 두 회사 모두 비상장회사인 거래에 대해 프리미엄과 공시 주가반응 분석이 이루어질 필요가 있다. 특히 국내 인수합병시장에서 사모펀드(PEF)가 차지하는 비중이 높아짐에 따라 사모펀드가 인수회사인 거래에 대해 분석이 이루어질 필요가 있을 것이다.17) 그런데 저자들이 확인한 바로는 $\mathrm{SDC}$ 데이터베이스에서 내려받을 수 있는 국내 지분매입 인수거래 목록에서는 사모펀드가 인수기업으로 참여한 거래들이 누락되어 있어서 별도의 자료수집 노력이 필요할 것으로 예상된다.

또한 본 연구는 지분매입 거래에서 프리미엄이 음(-)인 거래의 비중이 높다는 결과를 보고 하는데, 이 결과의 이면에는 어떤 요인들이 존재하는가 후속 연구를 통해 심층 분석할 필요가 있다. 피인수기업의 경영성과와 전망이 나쁠 경우 대주주가 싼 값에 자신의 지분을 넘길 가능성을 생각할 수 있겠지만 본 연구의 회귀분석 결과에 의하면 $\mathrm{ROA}$ 와 $\mathrm{M} / \mathrm{B}$ 으로 측정한 피인수기업의 성과는 프리미엄의 크기와 유의적인 관계가 나타나지 않았다. 그런데 인수기업과 피인수기업 간 지분거래가 시간외 대량매매(블록딜)의 형태로 이루어지는 경우가 많다고 가정할 경우 블록딜의 체결가격 구조를 분석함으로써 위 질문에 대한 해답을 찾을 수도 있지 않을까 생각된다. 국내 블록딜은 당일 종가보다 낮은 가격에 체결되는 경향이 있다는 투자자들의 간헐적인 증언들이 있는데, Khil et al.(2005)의 분석에서도 시간외 대량매매의 체결가격이 당일 종가보다 낮은 거래의 비중이 상당히 높음을 보고하고 있다(해당 논문 <그림 3(b)>). 따라서 블록딜의 체결가격 구조를 분석함으로써 위 질문에 대한 해답을 일부 얻을 수 있지 않을까 판단된다.

17) 금융감독원의 보도자료(2019)에 따르면 사모펀드( $\mathrm{PEF}$ (즉, 경영참여형 사모투자집합기구)의 수는 2018 년 기준 583 개이며 2009 년의 110 개에 비해 5.3 배 증가하였다. 
한국증권학회지 제49권 5 호 (2020)

\section{References}

Andrade, G., M. Mitchell, and E. Staffold, 2001, New Evidence and Perspectives on Mergers, Journal of Economic Perspectives, Vol. 15 (2), pp. 103-120.

Byun, J., and S. Ahn, 2007, Acquirer's Firm Size and Stock Market Response to M\&A Announcement, Asian Review of Financial Research, Vol. 20 (2), pp. 37-68.

Cho, J., and S. Jun, 2004, The Effect of Corporate Governance on Performance of Mergers and Acquisitions, Korean Journal of Financial Management, Vol. 21 (2), pp. 1-25.

Dyck, A., and L. Zingales, 2004, Private Benefits of Control: An International Comparison, Journal of Finance, Vol. 59 (2), pp. 537-600.

Fuller, K., J. Netter, and M. Stegemoller, 2002, What Do Returns to Acquiring Firms Tell Us? Evidence from Firms That Make Many Acquisitions, Journal of Finance, Vol. 57 (4), pp. 1763-1793.

Kang, H., and S. Kim, 2009, The Effect of M\&A Announcements on Acquiring Firms' Shareholders, Asian Review of Financial Research, Vol. 22 (3), pp. 73-112.

Kang, J., and J. Kim, 2008, The Geography of Block Acquisitions, Journal of Finance, Vol. 63 (6), pp. 2817-2858.

Khil, J., Y. S. Park, J. Shin, and J. Lee, 2005, Studies on the Impact of Block Tradings and Information Leakage on Market Performance, Korean Journal of Financial Studies, Vol. 34 (3), pp. 139-182.

Kim, B., and J. Jung, 2015, The Size Effect and the Diversification Effect of M\&As Depending on the Level of Capital Market Development, Korean Journal of Financial Studies, Vol. 44 (3), pp. 547-575.

Kim, H., 2012(a), Control Premium in Corporate Control Contests, Human Right and Justice, Vol. 427, pp. 81-94.

Kim, S., 2015, Control Premiums and Minority Shareholder Protection, Korean Journal of Financial Management, Vol. 32 (3), pp. 203-226.

Kim, W., 2012(b), Investor Protection and the Mode of Acquisition: Implications for Ownership Dilution and Formation of Pyramids, Financial Management, Vol. 41 (1), pp. 55-93.

Liao, R. C., 2014, What Drives Corporate Minority Acquisitions Around the World? The Case for Financial Constraints, Journal of Corporate Finance, Vol. 26, pp. 78-95.

Lim, S., C. Lee, and W. Jeon, 2010, The Effects of Corporate Characteristics and M\&A Types on the M\&A Performances in Kosdaq, Review of Accounting and Policy Studies, Vol. 15 (2), pp. 91-118.

Moeller, S. B., F. P. Schilingemann, and R. M. Stultz, 2005, Wealth Destruction on a Massive 
Premiums and Stock Price Responses in Equity-Stake Purchase Deals in Korea's Stock Market

Scale? A Study of Acquiring-Firm Returns in the Recent Merger Wave, Journal of Finance, Vol. 60 (2), pp. 757-782.

Na, J., and J. Baek, 2015, A Study of an Acquisition Method on Announcement Effect, Korea Corporation Management Review, Vol. 22 (1), pp. 21-41.

Park, K. S., C. Jung, and S. M. Kim, 2017, Policy Measures for M\&A Laws and Regulations in Korea: Focused on Reinforcement of Minority Shareholder Rights, Korean Journal of Financial Studies, Vol. 46 (1), pp. 1-33.

Park, K. S., C. Jung, and S. M. Kim, 2018, Investors Already Know what Controlling Shareholders will do this Summer: A Study on the Conflicts of Interests between Controlling Shareholders and Minority Shareholders in Affiliated Mergers, Korean Journal of Financial Studies, Vol. 47 (5), pp. 741-777.

Povel, P., and G. Sertsios, 2014, Getting to Know Each Other: The Role of Toeholds in Acquisitions, Journal of Corporate Finance, Vol. 26, pp. 201-224.

Quimet, P., 2013, What Motivates Minority Acquisitions?: The Trade-off between a Partial Equity Stake and Complete Integration, Review of Financial Studies, Vol. 26 (4), pp. 1021-1047.

Servaes, H., 1991, Tobin's Q and the Gains from Takeovers, Journal of Finance, Vol. 46 (1), pp. 409-419.

Suh, J., 2016, M\&A Premiums should not be Monopolized by Controlling Shareholders, Dong- $A$ Business Review, Issue 2 (197).

Yeh, T. M., 2019, An Empirical Analysis of Private Equity Buyouts via Private Investment in Public Equity vs. Tender offer, Working Paper, Kyushu University. https://www.sfm.u rl.tw/php/Papers/CompletePaper/076-837080399.pdf.

Yilmaz, I. S., and B. Tanyeri, 2016, Global Merger and Acquisition (M\&A) activity: 1992-2011, Finance Research Letters, Vol. 17, pp. 110-117.

Yun, J., and M. Jung, 2009, The Effect of Market Valuation on Corporate Acquisitions, Asian Review of Financial Research, Vol. 22 (1), pp. 63-98. 


\section{〈부록〉}

〈부록 1〉 국내 선행연구와 본 연구의 주가반응 비교

패널 $\mathrm{A}$ 는 합병거래를 분석한 주요 국내 선행연구의 주가반응 분석 결과를 요약하고 패널 $\mathrm{B}$ 는 지분 인수거래에 대한 국내 선행연구의 주가반응 분석 결과를 요약하며 패널 $\mathrm{C}$ 는 지분거래를 분석한 본 연구의 주가반응 분석 결과를 요약한다. “(+) 유의”는 보고된 평균 주가반응이 양의 유의성을 가지는 경우이며, “(+) ?”는 평균 주가반응이 양이지만 유의성은 보고되지 않은 경우이며, N/A는 피합병기업 또는 피인수 기업을 분석하지 않은 경우이다.

패널 $\mathrm{A}$ : 합병에 대한 선행연구

\begin{tabular}{|c|c|c|c|c|}
\hline 저자(발행연도) & 합병기업 & 피합병기업 & 표본기간 & 이벤트 윈도우 표본의 성격과 크기 \\
\hline Cho and Jun(2004) & $(+)$ ? & $(+) ?$ & $1992 \sim 2002$ & $\begin{array}{c}\mathrm{CAR}(-10,10) \text { 합병기업이 상장사 } \\
\text { (139건) }\end{array}$ \\
\hline Byun and Ahn(2007) & (+) 유의 & $\mathrm{N} / \mathrm{A}$ & $1998 \sim 2005$ & $\begin{array}{l}\text { 합병기업이 상장사 } \\
\text { (264건) }\end{array}$ \\
\hline Kang and $\operatorname{Kim}(2009)$ & (+) 유의 & $\mathrm{N} / \mathrm{A}$ & $2000 \sim 2008$ & $\begin{array}{l}\text { 합병기업이 상장사 } \\
\text { (396건) }\end{array}$ \\
\hline Yun and Jung(2009) & (+) 유의 & $\mathrm{N} / \mathrm{A}$ & $2001 \sim 2007$ & $\begin{array}{l}\mathrm{CAR}(-1,1) \quad \text { 합병기업이 상장사 } \\
\mathrm{CAR}(-10,10) \text { (334건) }\end{array}$ \\
\hline Lim et al.(2010) & (+) 유의 & $\mathrm{N} / \mathrm{A}$ & $2000 \sim 2005$ & $\begin{array}{c}\mathrm{CAR}(-20,20) \text { 합병기업이 코스닥시징 } \\
\text { 상장사(82건) }\end{array}$ \\
\hline Kim and Jung(2015) & (+) 유의 & N/A & $2001 \sim 2012$ & $\begin{array}{l}\mathrm{CAR}(-1,1) \sim \text { 합병기업이 상장사 } \\
\operatorname{CAR}(-5,1) \quad(1,293 \text { 건 })\end{array}$ \\
\hline
\end{tabular}

패널 B: 지분 인수거래에 대한 선행연구

\begin{tabular}{|c|c|c|c|c|c|}
\hline 저자(발행연도) & 인수기업 & 피인수기업 & 표본기간 & 이벤트 윈도우 & 표본의 성격과 크기 \\
\hline 然 & $\begin{array}{l}\text { 유의성 } \\
\text { 없음 }\end{array}$ & N/A & $2006 \sim 2011$ & $\begin{array}{l}\operatorname{CAR}(-1,1) \\
\operatorname{CAR}(-3,3)\end{array}$ & $\begin{array}{l}\text { 인수기업이 상장사 } \\
\text { (86건) }\end{array}$ \\
\hline
\end{tabular}

패널 C: 지분 인수거래에 대한 본 연구

\begin{tabular}{cccccc}
\hline 저자 (연도) & 인수기업 & 피인수기업 & 표본기간 & 이벤트 윈도우 & 표본의 성격과 크기 \\
\hline 본 논문(2020) & $\begin{array}{c}\text { 유의성 } \\
\text { 없음 }\end{array}$ & $(+)$ 유의 & $2009 \sim 2017$ & $\mathrm{CAR}(-2,2)$ & $\begin{array}{c}\text { 인수·피인수기업 모두 } \\
\text { 상장사(160건) }\end{array}$ \\
\hline
\end{tabular}


Premiums and Stock Price Responses in Equity-Stake Purchase Deals in Korea's Stock Market

〈부록 2〉연구표본 구축 과정

$\mathrm{SDC}$ 데이터베이스를 사용해 지분매입 거래 표본을 구축한 과정을 서술한다.

\begin{tabular}{|c|c|}
\hline 단계 $(1-9)$ & 거래 건수 \\
\hline $\begin{array}{l}\text { 1. 2009/01/01 2017/12/31 기간 전체 인수합병 공시 중 유효한(completed) 거래(인수기업과 } \\
\text { 피인수기업 모두 한국기업인 경우). }\end{array}$ & 7,861 \\
\hline $\begin{array}{l}\text { 2. 대량 지분매입(acquisition of majority interest)과 일부 지분매입(acquisition of partial } \\
\text { interest)만 선정. 따라서 합병, 자산양수도, 역인수 등은 제외. }\end{array}$ & $(2,206)$ \\
\hline $\begin{array}{l}\text { 3. 인수기업, 피인수기업 또는 양자 모두 비상장기업인 거래와 공개매수(tender offer) 형태의 } \\
\text { 거래 제외. }\end{array}$ & $(5,084)$ \\
\hline 4. 인수기업, 피인수기업 또는 양자 모두 금융회사일 경우 제외. & (105) \\
\hline $\begin{array}{l}\text { 5. 거래 결과 인수기업이 피인수기업 지분을 } 100 \% \text { 확보하게 되는 경우와 } 5 \% \text { 미만의 지분을 } \\
\text { 인수하는 거래 제외. }\end{array}$ & (51) \\
\hline $\begin{array}{l}\text { 6. 동일 인수기업에 대해 한해 다수의 거래가 존재할 경우 그 해의 첫 번째 거래만 포함. } \\
\text { 이와 유사하게 동일 피인수기업에 대해 한해 다수의 거래가 존재할 경우 그 해의 첫 } \\
\text { 번째 거래만 포함. }\end{array}$ & $(74)$ \\
\hline 7. 취득지분, 거래대금, 프리미엄 자료가 누락된 지분 인수거래는 제외. & (168) \\
\hline 8. CAR을 구할 수 없는 거래 제외. & $(10)$ \\
\hline 9. 본 논문 회귀식의 독립변수가 누락된 거래 제외. & (3) \\
\hline 최종 표본 & 160 \\
\hline
\end{tabular}

〈부록 3〉 변수 정의

분석에 사용된 변수를 정의한다. 프리미엄, 취득지분, 거래대금, 소속 산업 등은 $\mathrm{SDC}$ 데이터베이스에서 수집하였으며, 기타 변수는 에프앤가이드에서 수집하였다. 총자산 등 재무제표변수는 거래 직전년도 수치를 사용하였다.

\begin{tabular}{ll}
\hline 프리미엄(1 Day) & (주당 거래가격-공시 1일전 종가)/공시 1일전 종가(본문의 식 (1)) \\
프리미엄(1 Week) & (주당 거래가격-공시 1주전 종가)/공시 1주전 종가(본문의 식 (2)) \\
취득지분 & 해당 거래에서 인수기업이 취득한 피인수기업의 지분 크기 \\
프리미엄금액(1 Day) & (거래대금-(공시 1일전 종가×취득주식 수))/인수기업의 직전년도 총자산 \\
프리미엄금액(1 Week) & (거래대금-(공시 1주전 종가×취득주식 수))/인수기업의 직전년도 총자산 \\
거래대금/총자산 & 거래대금/인수 또는 피인수기업의 직전년도 총자산 \\
$\mathrm{ROA}$ & 영업이익/총자산 \\
$\mathrm{M} / \mathrm{B}$ & (총자산-자본의 장부가치+자본의 시장가치)/총자산 \\
동종업계 더미 & 인수기업과 피인수기업의 산업이 동일한 경우 1아니면 0(SDC 데이터베이스의 \\
& Macro Industry) \\
기업규모 & 총자산에 자연로그를 취한 값 \\
부채비율 & (단기부채+장기부채)/총자산 \\
대주주 지분율 & 최대주주 및 특수관계인의 보유지분 \\
\hline
\end{tabular}

